\title{
Sustainable Procurement: Comparing In-House and Outsourcing Implementation Modes
}

Maysara Sayed $^{\mathrm{ac}}$, Linda C. Hendry ${ }^{\mathrm{b}, *}$ and Marta Zorzini Bell ${ }^{\mathrm{bd}}$

${ }^{a}$ University of Edinburgh Business School, Edinburgh, UK

${ }^{b}$ Department of Management Science, Lancaster University Management School, Lancaster, UK

'Since submitting the paper, Maysara Sayed has moved to work as a Senior Data Scientist in Tao Leadership, UK.

${ }^{\mathrm{d}}$ Since submitting the paper, Marta Zorzini Bell has moved to Leeds University Business School, University of Leeds, UK

*corresponding author email: 1.hendry@lancaster.ac.uk

Maysara Sayed https://orcid.org/0000-0002-3836-3021,

Linda C. Hendry https://orcid.org/0000-0003-4186-4908 and

Marta Zorzini Bell https://orcid.org/0000-0002-0151-2169 


\title{
Sustainable Procurement: Comparing In-House and Outsourcing Implementation Modes
}

\begin{abstract}
Sustainable supply chain management practices can be particularly difficult to implement when the responsibility for sustainable procurement (SP) rests with buyers employed by a contractor, rather than an in-house procurement team. Yet there is no extant research that investigates the effect of outsourcing on SP. To address this research gap, this paper uses multi-case study data to explore the impact of outsourcing versus in-house implementation modes in the pursuit of SP. The findings suggest that each implementation mode has distinctive challenges and facilitators. However, by considering Transaction Cost Economics, results reveal that the advantage of outsourcing to professionals, with well-established SP expertise, brings information asymmetries in developing initial outsourcing contracts, which can lead to poorer sustainability performance than initially expected. Furthermore, when applying Principal Agency Theory, results suggest that sustainable performance can be improved in the long term through the effective design of well-constructed contractual relationships as SP maturity increases.
\end{abstract}

Keywords: Sustainability; Procurement; Outsourcing; Higher Education; Food \& Catering.

\section{Introduction}

Sustainable procurement (SP), has been defined as 'managing all aspects of the upstream component of the supply chain to maximize triple bottom line performance' (Pagell, Wu \& Wasserman, 2010, p.58), where the triple bottom line (TBL) refers to environmental, social 
and economic performance (Elkington, 1999). A growing body of research has investigated this issue, looking at topics including sustainable procurement performance across supply chain tiers (Ghadge et al., 2019); critical success factors for sustainability in the Indian automobile industry (Luthra et al., 2018) and supplier development in the context of sustainability (Zhang, Pawar \& Bhardwaj, 2017). Yet there has been no research to date that addresses the particular challenges associated with SP when the procurement function is itself outsourced and therefore carried out by buyers not employed by the focal firm. This is commonly the case when a focal company chooses to sub-contract an aspect of its operation which is a non-core part of its business expertise, as often occurs in the public sector. For example, it has been reported that $23 \%$ of UK Universities outsource all three of the following services: cleaning, catering and security (National Union of Students, 2013). Thus, the responsibility for the sustainable procurement of items such as: cleaning equipment; food; and uniforms rests with buyers who are employed by the respective contractor. The particular challenges, costs and facilitators associated with SP in this context may vary in comparison to instances in which the procurement function is managed in-house and it is therefore argued that this is an important gap to address in the SP literature.

The same research gap exists in the outsourcing literature. Whilst this literature has begun to discuss the role of sustainability considerations on outsourcing decisions (e.g. see Li, Okoroafo \& Gammoh., 2014; Bhamra, 2012), as yet, it has not identified the sustainability challenges, risks and success factors associated with SP in the context of in-house versus outsourced implementation modes.

It is argued here that these two implementation modes are distinctly different. In the outsourced mode, it is the sub-contractor that has the responsibility to implement the SP agenda of the focal firm. Thus, for example, in the typical case of University catering introduced above, the contractor would have the ultimate responsibility for sustainably sourcing the food 
and drink for the University. Yet the customer may be unaware of this delegated responsibility when the food and drink is sold at a retail outlet on the University premises, and thus the customer may attribute the responsibility to the University. Therefore, the reputation of the University rests firmly on the actions of the contractor, despite the University having, potentially, more limited control of the buyers (as conceptualised in general terms by authors such as Hofmann et al., 2014). Thus, while the University management have a direct relationship with buyers in the 'in-house' implementation mode, they have only an indirect relationship with buyers in the 'outsourcing' mode, as their main relationship is with the management of the contractor. Effectively, the University become one supply chain tier further away from their desired influence on the buyers. This is significant, given that authors such as Ghadge et al. (2019) argue that SP performance is not uniform across the supply chain, but instead the more significant improvements occur at the downstream end of the chain. This difference in relationship with the buyers may mean that different processes are needed to appropriately influence the buyers, and thereby implement SP in the two contexts. Further research is needed to examine these two implementation processes for the pursuit of SP and to determine whether this difference is significant in terms of how the function of SP should be planned and controlled.

Consequently, this paper aims to address the research gap outlined above by understanding these alternative implementation modes in the context of the pursuit of SP, focussing on their relative challenges, facilitators and competitive advantages, by asking the following research question:

RQ: How do in-house versus outsourced implementation modes affect the pursuit of sustainable procurement?

This research question is addressed using multiple case study research, conducted in the context of food procurement in the UK Higher Education (HE) sector. Given that the 
alternative implementation modes of in-house versus outsourced SP have not been studied in the extant literature, further exploratory research is needed. The choice of a case study approach has been argued to be an appropriate method for exploratory research that aims to be theorygenerating (Voss, Johnson \& Godsell, 2016; Ketokivi \& Choi, 2014). Thus, the case study approach is argued to be appropriate here, given the need to gain an in-depth understanding of the two implementation modes. University food and catering services are argued to be an appropriate context for this research, given that SP is being pursued via two different implementation modes: both in-house catering and outsourced catering.

The case studies were therefore selected, using the theoretical sampling approach, to ensure inclusion of the two implementation modes (Eisenhardt, 1989a; Voss, Johnson \& Godsell, 2016; Yin, 2018). In addition, within the HE context, there has also been increasing concern around sustainability within food and catering procurement processes, given the direct impact of these services on the health of the end customers, including both students and staff (Universities UK, 2013). Moreover, sustainable food has gained importance, more broadly in society as a direct result of national media coverage of food hygiene and animal disease issues (Oglethorpe \& Heron, 2013). For example, the outbreak of foot-and-mouth disease in 2001 and the horse meat scandal in 2013, have brought to light significant consumer concerns in the past.

The paper makes three main contributions to the literature. Firstly, it provides an indepth understanding of how the implementation mode differs using an in-house versus an outsourced mode of SP implementation, thereby clarifying that there is a distinct difference between the two modes, despite the SP related objectives being similar in both cases. In particular, this paper explores how the distinctly different facilitators for the pursuit of SP, challenges, and supporting advantages of the two implementation modes contribute, or not, towards the focal firm achieving their sustainability-related objectives. Secondly, by applying Transaction Cost Economics (TCE) as a theoretical lens, the work provides three propositions 
on the approaches that can be taken to reduce the strategic costs associated with SP for each implementation mode. Thirdly, by applying Principal Agency Theory (PAT), a fourth proposition argues that the relationship between the principal (the focal organisation) and its SP agents (the contractor in the outsourcing mode or the buyers in the in-house mode) will change over time as knowledge surrounding SP matures. The paper concludes by arguing that whilst the research presented here has focused on the implementation of SP in the food \& catering services of a University, the findings are more generally relevant to organisations considering make versus buy implementation modes involving innovative practices, of which SP is just one example.

The paper continues with a review of the relevant literature, followed by a detailed justification of the research methodology. The findings regarding the two distinct implementation modes are outlined next, before being discussed by: firstly, explaining the application of TCE as a theoretical lens; secondly, building on the application of TCE to describe both the short-term and potential long-term relative costs for both implementation modes; and thirdly, using PAT as an additional complementary theoretical lens. Finally, conclusions are drawn, including managerial implications, limitations and opportunities for further research.

\section{Literature Review}

Sustainability in the context of supply chain management has become an increasingly popular area of research, leading to a number of key literature reviews and conceptual papers - see for example: Glock, Grosse \& Reis (2017); Chen et al. (2107); Zorzini et al. (2015); Ashby, Leat \& Hudson-Smith (2012); Seuring \& Mueller (2008). Such papers clarify that environmental sustainability issues that have been researched include recycling, reverse logistics and life cycle analysis along with many other concerns related to the conservation of the natural environment 
(Ashby, Leat \& Hudson-Smith, 2012). Social sustainability is defined to cover issues related to human rights, promotion of gender equality in the supply chain and health and safety, amongst others - see Zorzini et al. (2015) for a comprehensive list. Some topics within this spectrum have recently gained more attention, such as emerging research on the topic of modern slavery and how to combat this within the supply chain (see for example Benstead, Hendry \& Stevenson, 2018). Within this broad set of literature, prior studies that are focused on SP are the most relevant to the research presented in this paper. These studies are reviewed in the first sub-section below. As the majority of these papers implicitly assume an in-house implementation mode, research on outsourcing versus in-house functionality is discussed next, particularly focusing on extant papers that consider sustainability issues. In the final subsection, the review clarifies the use of TCE and PAT as theoretical lenses.

\section{Sustainable Procurement (SP)}

In their review of the socially and environmentally responsible procurement literature, Hoejmose \& Adrien-Kirby (2012) identified three main themes: (1) drivers and pressures for adopting SP practices; (2) SP implementation processes and techniques; and (3) the relationship between SP and the performance outcomes. These key themes continue to feature in the growing body of literature on sustainable procurement, as confirmed by authors such as Yawar \& Seuring (2017) in their more recent review of social sustainability issues in supply chains. For example, within the second category, the SP implementation processes and techniques described in the existing literature to date include supplier codes of conduct, sustainable supplier selection, collaboration and communication with suppliers, monitoring and auditing efforts, and SP disclosure and reporting (e.g. see Jiang, 2009; Walker \& Brammer 2012; Mansi, 2015; Macchion et al., 2018). This literature also discusses the barriers and problems related to sustainability implementation, such as financial costs, compliance 
problems, supplier sustainability capabilities and cultures, (e.g., see Ageron, Gunasekaran \& Spalanzani, 2012; Huq, Stevenson \& Zorzini, 2014). Within the third category by Hoejmose \& Adrien-Kirby (2012) - the relationship between SP and performance outcomes - the previous literature suggests that competitive advantage from SP arises by enhancing a company's reputation and market share, i.e. gaining legitimacy through complying with government regulations and meeting stakeholders' expectations, or increasing customer satisfaction and cost reduction in the long-run (Preuss, 2009; Ageron, Gunasekaran \& Spalanzani, 2012; Chen and Slotnick, 2015). Additionally, the previous performance outcomes are not only limited for the companies that practice SP, but they can also be extended to their suppliers' performance through implementing sustainable supplier development strategies and programs (Gimenez and Tachizawa, 2012; Blome, Hollos \& Paulraj, 2014; Zhang, Pawar \& Bhardwaj 2017). Furthermore, this relationship between SP and company performance can also exist in the reverse way - where, from a legitimacy theory point of view, the superior market performance (measured through reputation, image and market share position) can positively promote SP practices (Blome, Hollos \& Paulraj, 2014). However, Ghadge et al. (2019) suggest that performance improvements are not uniform across the supply chain, with the more significant improvements in the tiers closest to the customers.

In terms of research into specific types of organisation in the context of SP, there has been a lack of research to date that focuses on the specific issues of the public sector (e.g. Brammer \& Walker, 2011), of which outsourcing versus in-house implementation modes is one such issue. Most of this prior research has studied specific sectors, such as local government (Walker \& Preuss, 2008) and state-owned enterprises (Mansi, 2015). There are just two studies that have taken a cross sectional approach involving several types of public sector organisation (Walker \& Brammer, 2009; Brammer \& Walker, 2011). In particular the HE sector has received very little attention, with just three published studies that have discussed 
sustainability in the context of the HE procurement function (Bala et al., 2008; Young, Nagpal \& Adams, 2015; Sayed, Hendry \& Zorzini Bell, 2017). The first of these focuses on environmental initiatives only, whilst Young, Nagpal \& Adams (2015) suggest that a current focus in HE procurement is the inclusion of sustainability issues within supplier contracts, and Sayed, Hendry \& Zorzini Bell (2017) investigate the different institutional pressures and logics affecting three tiers of the food supply chain with Universities as the focal tier. Overall, the themes that have been studied in the context of the public sector are similar to those studied in the broader SP literature, with the focus on drivers and enablers and the implemented SP practices, however, no papers as yet consider the impact on overall performance. Therefore it can be concluded that none of the prior SP literature looks at the impact of outsourcing versus in-house SP implementation modes on performance; nor do they compare the implementation processes for SP in the two contexts.

\section{Outsourcing versus in-House Functionality and Sustainability}

A main focus of the prior research into the make-or-buy decision has been to identify the appropriate decision-making criteria (e.g. Canez, Platts \& Probert, 2000; Bhamra 2012). This literature is well developed, with a number of papers also identifying the benefits and risks of outsourcing compared with in-house production (e.g. Kremic, Tukel \& Rom, 2006; Jain \& Khurana, 2013). Many of these papers suggest, for example, that outsourcing will reduce costs (e.g. Jain \& Khurana, 2013), whilst others refer to the hidden costs that can, in fact, outweigh any short-term financial benefits (e.g. Kremic, Tukel \& Rom, 2006). Thus there is no consensus in the literature on these risks and benefits. Instead, it is argued that this is a difficult decision which depends on the context, and therefore models that guide this decision-making process are the most fruitful avenue for research (Canez, Platts \& Probert, 2000). It follows that such models need to include reference to a comprehensive set of criteria to consider. However, as 
yet, there are only a limited number of papers that consider sustainability as one of the factors influencing the make-or-buy decision or that consider sustainability-related issues in terms of the associated risks and benefits. In addition, the extant research focusses primarily on the manufacturing context. Given that the context of this paper is to consider SP in a services context, the following discussion looks first at papers that have considered sustainability in an outsourcing decision context, before briefly reviewing the literature that focusses on outsourcing services.

Studies that look at sustainability in an outsourcing versus in-house context include: Brown (2008), Antonio (2011), Bhamra (2012), Mendoza \& Clemen (2013) and Moosavirad, Kara \& Hauschild (2014), and can be categorised into (1) papers that focus on the outsourcing versus in-house decision or (2) papers that look at sustainable outsourcing once the decision to outsource has been made. In the first category, Bhamra (2012) found through survey research that sustainability is still not a key criterion when deciding whether to outsource or retain inhouse functionality. Yet, it has been argued by authors such as Moosavirad, Kara \& Hauschild (2014) that the decision to outsource can have a significant impact on sustainability measures. This research is limited as there is only one measure for each of the environmental and social dimensions - $\mathrm{CO}^{2}$ emissions and unemployment levels respectively - but suggests a need for practicing managers to further understand the impact of outsourcing on sustainability. Papers in the second category draw similar conclusions to those already reviewed in the previous subsection, looking at the SP literature, by suggesting that companies are beginning to introduce sustainability initiatives for their outsourced activities, such as the use of codes of conduct and public reporting (Antonio, 2011).

In the context of outsourcing services, logistics and IT outsourcing have received the most attention to date (e.g. Ulbrich \& Schulz, 2014; Suyabatmaz, Altekin \& Sahin, 2014; Bajec, Tuljak-Suban \& Krmac, 2015). Some of these papers identify specific challenges for 
the service researched - for example Ulbrich \& Schulz (2014) indicate that key challenges for outsourcing IT include communication between IT and non-IT staff. Only a small number of these papers consider sustainability, and these focus on environmental concerns - for example Bajec, Tuljak-Suban \& Krmac (2015) show that there is no relationship between the implementation of quality standards and investment in environmental priorities for logistics service providers. In these papers, again the focus is on the operational aspects of outsourcing after the decision to outsource has been made. Catering has received less attention, and papers that do consider catering do so without considering the sustainability agenda e.g. Natukunda, Pitt \& Nabil (2013). When catering is outsourced, this will tend to include its associated procurement function. However, the outsourcing of the procurement function - which can be considered to be a service in its own right - has received limited attention in the literature (Brewer, Wallin \& Ashenbaum, 2014; Brewer, Ashenbaum \& Carter, 2013). Both the Brewer, Wallin \& Ashenbaum (2014) and Brewer, Ashenbaum \& Carter (2013) papers look at the relationship between manufacturing and the procurement function in the electronics industry, again without any explicit consideration of the sustainability agenda. These papers stress the importance of future research into the outsourcing of procurement, quoting the extant literature that (i) estimates that purchased goods and services can account for $50-90 \%$ of a firm's cost of goods sold (Emiliani, 2010) and (ii) suggests that procurement should be outsourced with caution given its crucial boundary spanning role with suppliers (Kerkfeld \& Hartman, 2012).

In conclusion, further research is needed to assist the service sector in determining whether to provide in-house or outsourced services, when looking to include an understanding of sustainability-related benefits and risks, thereby providing evidence of the impact that this decision will have on their sustainability agenda. In particular, the impact of in-house versus outsourced SP is not included in this literature to date. Yet this is an important topic to research as the impact on sustainability of outsourcing the procurement function is likely to have a 
profound and far reaching effect given the complexity of modern global and fragmented supply chains. A theoretical lens is needed for this purpose, and the following section reviews the use of TCE and PAT to determine whether they are appropriate choices to address this research gap.

Transaction Cost Economics (TCE) and Principal Agency Theory (PAT) as Theoretical Lenses

TCE theory has been used in the extant literature to aid in determining whether it is better to carry out activities internally or to outsource (e.g., Wang, 2002; Williamson, 2008; McIvor, 2009; Brewer, Ashenbaum \& Carter, 2013). Whilst there has been recent criticism of aspects of the theory by Kelly, Wagner \& Ramsay (2018), TCE's constructs, such as opportunism, asset specificity and uncertainty, have all been argued to play an important role in the outsourcing decision and its subsequent success (McIvor, 2009; Wang, 2002). For example, it has been argued that TCE suggests that: when the company expects high levels of opportunistic behaviour from suppliers and there is high asset specificity and uncertainty surrounding the transaction, then an internal (in-house) mechanism is preferred to the market (outsourcing) mechanism (McIvor, 2009; Brewer, Ashenbaum \& Carter, 2013). In contrast, in a study of customised software outsourcing practices in Taiwan, Wang (2002) found that asset specificity has a negative effect on post-contractual opportunism and a positive effect on outsourcing success. Whilst this appears to contradict TCE theory, it can be explained by the huge specific investment, especially human capital, skills and time, from both parties in 'customised' software outsourcing that leads to 'a mutual dependence, bilateral monopoly relationship' between outsourcer and contractor (Wang 2002). Thus, this would increase the cost of contract termination for both parties that might result from opportunistic behaviour, which is then in line with TCE theory. It can be argued, then, that the application of the TCE theory might lead 
to different conclusions, dependant on contextual factors related to the in-house versus outsourcing decision.

In the context of SP and supply chain management, TCE has been used in prior studies (e.g., Carter \& Rogers, 2008; Jiang, 2009; Pagell, Wu \& Wasserman, 2010). For example, TCE has contributed to the analysis of associated sustainability costs and risks in buyer-supplier transactions and relationships (e.g., Pagell, Wu \& Wasserman, 2010; Tate, Dooley \& Ellram, 2011). Despite its prior use in the extant SP literature, there are still opportunities for further use of TCE in this field (Touboulic \& Walker, 2015a). In particular, it is concluded here that there is a research gap to use TCE as a theoretical lens to study the impact of the outsourcing decision on the subsequent procurement within the context of the outsourced service. This is argued to be important because, for outsourced basic services (e.g., catering and cleaning services), where that service is then carried out on the premises of the buying organisation, that organisation then retains the responsibility of its contractor's procurement activities in the eyes of its customers and other stakeholders (Bhamra 2012). Bhamra (2012) also argued that TCE informs much of the outsourcing theory and practice today, and so is an important theoretical lens to apply to new research findings in this context.

In addition, PAT is concerned with the ongoing relationship between the two parties involved in a transaction, referred to as the principal (e.g., shareholders) and the agent (e.g., managers), where the agent is delegated to make decisions on behalf of the principal (Eisenhardt, 1989b). Although PAT employs similar assumptions to TCE, for example with regard to self-interest, bounded rationality and information asymmetry (Eisenhardt, 1989b), some authors argue that TCE is more broadly focused on determining suitable governance mechanisms, whereas PAT focuses more specifically on the ongoing contractual relationship between the principal and the agent (Sanderson et al., 2015). Thus, PAT has contributed in providing valuable insights on the types of contract that can be used to manage the relationship 
between a principal and an agent efficiently (e.g., behaviour-based contracts versus outcomebased contracts) (Logan, 2000). Given the lack of prior application of PAT in the context of SP (Touboulic and Walker, 2015a) and its focus on efficient contractual relationships between the parties involved in a transaction, it is argued that PAT can complement TCE in this context. Thus, as explained in the discussion section below, whilst TCE aids in understanding the costs of the transaction and evaluating governance mechanism choices, PAT then aids in understanding how the ongoing chosen governance mechanisms can be implemented through effective contractual relationship design.

In this paper, both TCE and PAT have been applied to the findings retrospectively, rather than being used up front to drive the investigation. This use of extant theory can be categorised as 'theory suggesting and explanation', as defined by Zorzini et al. (2105), in which theory is used to analyse the findings towards the development of propositions. As explained by Zorzini et al. (2015), this use of theory has been adopted in the extant literature when using an inductive research approach, as exemplified by authors such as Pagell, Wu \& Wasserman (2010). As justified in the following section, this paper also adopts an inductive research approach, and it is therefore concluded that this is an appropriate use of theory for the research project described herein.

\section{Research Method}

This paper aims to fill the research gaps identified in the literature review above through investigating the implementation of sustainability initiatives (both social and environmental) within the food and catering procurement practices of UK HE institutions. Given that the alternative implementation modes of in-house versus outsourced SP have not been studied in the extant literature, exploratory research is needed. Therefore, an inductive case study approach was adopted as the research method for this study, as this is argued to be an 
appropriate method for exploratory research that aims to be theory-generating (Voss, Johnson \& Godsell, 2016; Ketokivi \& Choi, 2014). This method enables researchers to collect rich and profound data to better understand the issues being explored (Eisenhardt \& Graebner, 2007; Yin, 2018). In addition, case study research can allow for the investigation of complex and real life phenomena in its natural and holistic settings using multiple data collection tools such as interviews, observations and document analysis (Eisenhardt, 1989a; Ackroyd, 2004; Easton, 2010; Yin, 2018). Thus, with regards to this research, the case study method enabled the investigation of the different modes of implementations associated with the incorporation of sustainability within the procurement functions of HE institutions, to gain real and in-depth knowledge of these modes (Eisenhardt, 1989a; Meredith, 1998; Yin, 2018), to explore contextual factors of the research settings (Ackroyd, 2004), and to reveal underlying causal mechanisms within each of them (Aastrup and Halldorsson, 2008).

\section{Case Selection and Data Collection}

The selection of the cases follows theoretical sampling principles, whereby each additional case either predicts similar results (a literal replication); or produces contrary results but for predictable reasons (a theoretical replication) (Eisenhardt, 1989a; Voss, Johnson \& Godsell, 2016; Yin, 2018). Five UK Universities were chosen as focal cases, with three that use the inhouse implementation mode (FHE1, FHE2 and FHE3) and two that use the outsourced implementation mode (FHE4 and FHE5). Therefore, for example, FHE4 and FHE5 are a matched pair, providing literal replication with each other, as they are both outsourcing Universities. They also provide theoretical replication with the other three Universities, given the difference in implementation mode. Other contextual factors for the three Universities are given in Table 1, including: their sustainability performance (where position in the Green League Table 2015 was used as a proxy for performance - see People \& Planet, 2015); city 
size and location within the UK. These factors were also considered in the data analysis stage to determine whether they could further explain any differences between the cases.

[Take in Table 1]

In addition to employees of the focal cases (universities), other key stakeholders who are involved in the implementation of their SP food \& catering initiatives have been interviewed including: two catering contractors and two purchasing consortiums. The catering contractors run the catering services for the outsourcing universities; therefore they have the responsibility to implement the university's sustainability agenda with regards to food and catering procurement. Likewise, the purchasing consortiums help in-house universities in the implementation of sustainability initiatives either through the development of supplier contracts or professional events and trainings.

The data collection process was completed in three stages; with preliminary data analysis conducted after each of the first two stages, as recommended by methodology scholars as a means of strengthening the data collection process (e.g. Voss, Johnson \& Godsell, 2016; Miles, Huberman \& Saldana, 2014). In this study, the preliminary analyses lead to some additional interview questions to ensure that issues that had commonly arisen in the early interviews were captured in all remaining interviews. The interview questionnaire scripts are included in the appendix, illustrating that the questions were modified according to the four categories of interviewee: universities using the 'in-house' implementation mode; outsourcing universities; contractors and purchasing consortiums. The data collection process was stopped when it was felt that the saturation level had been achieved, i.e., when no more significantly new data was being collected from interviews (Eisenhardt, 1989a). In total, 17 semi-structured face-to-face interviews were conducted. Table 2 provides details of each interviewee, indicating their organisational role and the nature of the organisation which employs them.

[Take in Table 2] 
In order to ensure the research quality appropriately at each phase of the research process, construct validity, internal validity, external validity and reliability measurements have been fulfilled. This is as recommended by authors such as Yin (2018) and Gibbert, Ruigrok \& Wicki (2008), and exemplified by authors such as Wilhelm et al. (2016) - see Table 3 for a summary of how this has been achieved. For example, to ensure construct validity during the data gathering phase, other secondary data and documents have been collected for triangulation purposes with the interview data. Secondary data sources include: the organisations' websites; published sustainability reports; and documents provided by the interviewees, such as suppliers' assessments questionnaires and protocols, sustainability policies and action plans. In addition, to ensure internal validity in the data gathering phase, at least two respondents have been interviewed about the implementation of sustainable food and catering initiatives for each case. To ensure external validity in the case selection phase, multiple cases have been chosen by replication logic (as discussed above). To ensure reliability in the design and data gathering phases, a case study protocol was developed, thereby enabling the same rigorous process of data collection to be used with all cases and respondents.

[Take in Table 3]

\section{Data Analysis}

The data analysis process was undertaken using a two-step procedure - in line with an inductive case study approach. The first step aimed to approach the data with an open mind, in order to gain a general overview and identify the main themes (Gibbs, 2002). During this step both within-case analysis and cross-case analysis was conducted (Eisenhardt, 1989a). The analysis began by preparing the data, coding it and then searching for patterns (Miles, Huberman \& Saldana, 2014). The codes used during this step were generated from the data itself in order to identify the new and interesting themes. The codes used were circulated between the three 
researchers for checking, revising and confirmation, with any initial disagreements resolved through discussion. The second stage of data analysis then aimed to relate the data to TCE and PAT, as well as other extant literature to gain further, deeper understanding and insights. Throughout the data analysis, coding was facilitated by the NVivo software and the unit of analysis was the implementation process for SP practices and initiatives within the context of the food and catering services of the University.

\section{Findings Overview}

The within-case analysis led to the identification of the sustainability practices and initiatives that have been implemented in each case (as shown in Table 4), and a full understanding of the associated SP implementation processes. Therefore, for each case, analysis was undertaken to determine the 'challenges' and 'facilitators' that affected the implementation process of SP specific initiatives. For example, in terms of the 'Food for life' accreditation, FHE1 were aiming to gain a Bronze Award at the time of the research. This was a major SP initiative for the University as it involved: understanding where food comes from; reducing food waste; ensuring the food is free from harmful ingredients; and increasing the $\%$ of fair-trade produce purchased. The 'challenges' associated with this included negotiating on prices for new, potentially more expensive local suppliers, and resistance from staff familiar with existing suppliers. However, the 'facilitators' for attaining the award included the level of control that senior managers could enforce. For example, Interviewee FHE1-I3 explained that he would always first aim to persuade buyers that change was necessary given the benefits of the Bronze Award, but if persuasion failed, he would sometimes 'tell them off in a really nice way' to enforce the change. In addition, the process was facilitated by the choice of a challenging but realistic initial target of the Bronze Award, with the intention to follow this up with Silver in the near future. 
[Take in Table 4]

The within-case analysis also involved developing a full understanding of the overall 'Sustainability-related strategic objectives' and the 'supporting advantages' which can be argued to aid each University in attaining these objectives. For example, the implementation of an 'Edible Campus' concept in FHE1 aimed to improve the visibility of sustainability initiatives across the campus, with free food available - such as herbs grown in containers on the main University walkways. This SP initiative addresses the 'sustainability-related strategic objective' of improving student satisfaction and the associated 'supporting advantages' include the 'ongoing flexibility' associated with the in-house management of internal buyers and suppliers.

Having developed this within-case analysis, the cross-case analysis indicated that all the Universities are similar in terms of the types of SP initiatives implemented in the focal Universities, as listed above in Table 4, with no clear patterns according to any of the case selection criteria. It is noted that only two of these SP initiatives are explicitly categorised as sourcing initiatives in Table 4. However, all of them have implications for sourcing. For example, 'Meat Free Mondays' categorised under 'Healthy Food' has an impact on the procurement requirements. It is also important to note that the five focal universities are also similar in terms of offering a variety of food and drinks outlets (e.g., restaurants, cafes, bars) which provide a range of food and drinks (e.g., hot meals, sandwiches, snacks, drinks); and they all provide hospitality services for meetings, events and conferences.

Although the SP initiatives along with the food and catering services are similar, the cross-case analysis led to the identification of clear differences in terms of SP implementation processes. These differences include: having direct or indirect responsibility and accountability for SP implementation; direct or indirect relationships with the suppliers; and external assistance though membership of purchasing consortiums. Here, clear patterns for the SP 
implementation processes associated with the outsourcing Universities were identified, which differ from the patterns found in the in-house cases. For example, in terms of their food policies, the two outsourcing universities (FHE4, FHE5) both clearly indicate in their food policies that they are responsible and accountable for their contractors' sustainability performance including their procurement and supply chain activities. Thus, although the outsourcing universities don't have a direct relationship with the actual suppliers of food and catering equipment, both universities have stated clearly in their food policy that they are indirectly committed to providing healthy and sustainable food for their students, staff and visitors. The Universities that operate in-house catering services also have similar sustainable food policies, which stipulate the minimum requirement for food and catering procurement activities. However, in this case the internal food and catering team, including buyers and chefs, have direct relationships with the suppliers and are hence directly responsible for the implementation of the policies. A particular distinguishing feature of the in-house implementation mode of FHE1, FHE2 and FHE3 are that they are all members of purchasing consortiums, including PC1. These consortiums aid members in conducting some of the procurement activities such as tendering, checking, selecting and monitoring suppliers. Hence, PC1 prepare a list of potential suppliers who meet the universities sustainability requirements at the best pricing available. However there is no obligation upon members to choose from this list - the Universities have complete freedom to use any other suppliers. Thus the university buys directly and has a direct relationship with its actual food and catering suppliers. Thus all five Universities have similar policies and hence similarities in terms of their sustainabilityrelated objectives, but there are clear differences in terms of the implementation process between the in-house and outsourced implementation modes. These differences in processes lead to differences in the 'facilitators', 'challenges' and 'supporting advantages'.

Figure 1 proposes a conceptual model, which both summarises the constructs (as 
underlined in Figure 1) and sub-constructs (listed under each construct) identified in the crosscase analysis of the findings; and also illustrates how these constructs are related to each other. On the bottom right, the specific sets of 'challenges', 'facilitators' and 'supporting advantages' associated with the 'Outsourced SP Mode' are shown. A similar picture emerges for the 'Inhouse SP Mode' in the bottom left of Figure 1. The University 'sustainability-related strategic objectives', are given across the top of Figure 1, as they are common across both implementation modes, albeit to a lesser or greater extent. Table 5 then defines each of the constructs and sub-constructs included in Figure 1, and includes illustrative sample quotes from a wide variety of interviewees to illustrate the triangulation of the findings. For example, for the main construct of 'sustainability-related strategic objectives', there are three subconstructs. Firstly, for the 'University Social Responsibility' indicated in Figure 1, the evidence suggests that the interviewees feel a strong inherent ethical obligation towards their communities to be socially responsible. For example FHE3-I1 stated: 'we should be seen as a benchmark, we should be seen as the role model for local businesses, ... '. This confirms the claims in the extant literature by authors such as Lozano et al. (2013). The second objective in Figure 1, a 'Sustainability Competitive Position', includes the aspiration to have a strong position in the Green League Table. For example, FHE4-I2 stated that: 'Getting higher points in the green league is our goal, ...we were quite close to the bottom and that was seen as being quite embarrassing...'. Therefore, FHE5 for example, has put their position in the Green League Table as one of their KPIs for sustainable performance as explained by FHE5-I2 'The one thing that we view helps drive stuff here at the university, and this has been a very fortunate thing for us, is that one of the university's four strategic KPIs happens to be our performance on the people and planet or in other words the universities league'. In addition for the larger City Universities, (FHE2, FHE4 and FHE5), there is a perceived need to be able to compete with high street brands, such as Costa and Starbucks - given that these options are easily 
accessible to the students. Thirdly, 'student satisfaction' on sustainability-related issues is also seen to be important in all 5 focal Universities, and refers to the existing students. For example, PC1 stated: 'quite often when we talk about sustainability, the opening statement from the members [universities] is: oh no, the students will go mad if we do something like that; or students are really big on this ... it's pleasing to hear that, because there is an acute awareness of who the customer is and the power that they ultimately have'.

[Take in Figure 1]

[Take in Table 5]

It is noted that the remaining constructs in Figure 1 are categorised in a different manner to those in the extant literature, using the labels of challenges, facilitators and supporting advantages, rather than the more common labels of 'benefits' and 'risks'. The constructs chosen were felt to be more appropriate as the evidence provides a more in-depth understanding of how the risks can be addressed in this setting. Nonetheless, it is noted that there are some similarities in the findings compared with the extant literature. In particular, the issue of costs arose in this study with the evidence suggesting that the in-house implementation mode leads to the increased costs associated with SP, whilst the outsourced mode leads to reduced costs for SP. This confirms the findings of authors such as Jain \& Khurana (2013), who also associate outsourcing with reduced costs, though not including the costs of sustainability in their discussion. However, as indicated by authors such as Kremic, Tukel \& Rom (2006), there can be hidden transaction costs associated with outsourcing, and this is also argued to be the case for SP related costs, as explained in the discussion section below. In addition, the prior literature has associated reduced flexibility with outsourcing (see Kremic, Tukel \& Rom, 2006), and there is a common argument that outsourcing is appropriate for non-core activities (McIvor, Humphreys \& Mcaleer, 1997), which is akin to the concept of 'professionalism' i.e. of outsourcing to experts. Thus the evidence in this study indicates that sustainability-related 
issues that apply in the HE context have also been found in other contexts. Thus this paper adds to the debate on whether outsourcing reduces costs and confirms findings related to flexibility and professionalism within the extant broader outsourcing and sustainability literature, but in a new SP context.

Despite this, there are also constructs in Figure 1 that have not been discussed in the existing literature. In particular, many of the facilitators - including 'sustainability passion' and 'purchasing consortium assistance' - bring a new dimension to the sustainability-related outsourcing literature. Thus the findings of this paper also add detail to the prior literature by providing a more in-depth understanding of the factors that affect the SP implementation process and the subsequent impact on performance. The relative importance of these new constructs is highlighted in the discussion below.

\section{Discussion}

\section{The Application of Transaction Cost Economics (TCE) Theory}

The TCE perspective indicates that the in-house mode makes use of vertical integration or hierarchical governance mechanisms in conducting SP activities, while the outsourcing mode makes use of the market governance mechanism (McIvor, 2009), as the contractor then undertakes the SP activities on the Universities' behalf. It is important to note that it is the relationship with the buyers responsible for SP activities that is key here - rather than the relationship with the suppliers of food and catering equipment. Key constructs of TCE can be used to explain the effects of the governance mechanisms at play when dealing with internal buyers versus the contractors' buyers. These are discussed below, and include: opportunistic behaviour, bounded rationality, uncertainty, information asymmetries and asset specificity.

In the outsourcing mode, the conflict between the interests of the university and the contractor, in terms of SP, increases the potential for opportunistic behaviour. As shown in 
Figure 1, the commercial contractor's focus on their own financial interests presents a challenge. However, the university may wish to influence the contractor to implement sustainability initiatives, even if it will increase overall costs (e.g., implementing food for life accreditation as seen in FHE5) or reduce profits (e.g., eliminating the plastic water bottles supply as also seen in FHE5). The contractor, in turn, has been shown to resist these pressures - especially if they are not specifically mentioned in the initial outsourcing contract (e.g., one of FHE5's contractors resisted applying for the food for life certificate). Thus it can be argued that there is a risk that the contractor will behave in an opportunistic way under this market governance mechanism, particularly when there is no contractual obligation to implement particular sustainability initiatives. This risk is compounded by uncertainty, bounded rationality, asset specificity and information asymmetries, as discussed in turn below.

In terms of uncertainty, this is high at the start of the outsourcing contract, given the rapid evolution in sustainability requirements and accreditation certificates (Pagell, Wu \& Wasserman, 2010). In addition, professionalism on the part of the contractor implies that University employees involved in the contract design have less expertise in terms of SP in the food and catering sector, and therefore, bounded rationality is at play to the University's disadvantage. This leads to incomplete ex-ante contracts (as noticed in both FHE4 \& FHE5). In addition, asset specificity favours the contractor side, as the university invests time and money to conduct the tender process and evaluate alternative contractors (it took around 8 months in the last tender process for FHE5). The only asset specificity for contractors, in this context, arises if they are required to apply for specific sustainability certificates for one of the university's outlets or to invest in specific sustainability equipment (e.g., waste recycling equipment), which cannot be used in other universities. This may explain why the contractor sometimes tries to renegotiate the contract with a university if it insists on new requirements as evidenced in both FHE4 \& FHE5 (Williamson, 2008). Therefore, it is more costly for the 
university to frequently change contractors, especially if the contractor's reputation is not adversely affected in the case of non-renewal of the contract (i.e. as they have complied fully with the contract during its period, but the reason for not renewing was contractor reluctance to go above and beyond the requirements of the contract to meet the University's sustainability objectives).

The bounded rationality on the part of the University in the context of contract development applies at all stages in relationships with its contractors, and therefore also includes the evaluation and service provision stages. Given the professionalism on the part of the contractor, information asymmetries can favour the contractor side at every stage. Therefore, there is a potential risk that the contractor may mislead the university in sustainability implementation, given the 'reduced control' construct (see Figure 1) experienced by the universities. Also the recent existence of sustainability in the agenda and the difficulty of measurement - when compared to other performance aspects, such as cost and quality compound this problem. Thus, although the evidence suggests that professionalism is a supporting advantage for the outsourcing mode, it can also be seen to increase opportunistic behaviour - thereby providing an indirect, disadvantageous cost.

In contrast, the facilitators (Figure 1) can help in reducing the potential contractor opportunistic behaviour and its risks. For instance, by developing a 'collaborative relationship' with the contractor, the governance mechanism can be shifted from a pure market mechanism to a more hybrid mechanism, where trust supplants singularity of market power to facilitate the implementation of sustainability initiatives and compensate for the incompleteness of the contract (as suggested by e.g., Williamson, 2008; McIvor, 2009; Jiang, 2009; Huq, Stevenson \& Zorzini, 2014). In addition, the university uses market power factors (such as the contractor's sustainability competitive position and reputation) during the tendering and evaluation processes. These factors work as safeguards for the university. However, they are not efficient 
alone to mitigate the contractor's opportunistic behaviour after the selection process ends. Therefore, having a good and cooperative working relationship that builds trust between the university and contractor is an important factor (as mentioned by both cases: FHE4 \& FHE5) to facilitate and ensure the implementation of sustainability practices.

In the in-house mode of implementation, the hierarchical mechanism gives the university the advantage of increased control over internal buyers implementing SP initiatives. This reduces any potential opportunistic behaviour from those buyers. Furthermore, the sustainability passion of buyers evidenced in the in-house cases further mitigates the risk of opportunism in this mode. Thus the TCE perspective further confirms the findings that ongoing flexibility is more inherent within the in-house implementation mode than the outsourced mode. It may also be concluded that the transaction costs overall are higher for the outsourced implementation mode than for the in-house implementation mode.

\section{The Relative Costs of the two Implementation Modes}

Although transaction costs are higher for the outsourced SP implementation mode - as discussed above - it can be argued that this is a short-term issue which may be offset by other costs associated with SP implementation. Within the in-house implementation mode, the direct costs (referred to in the literature as production costs in this context, e.g. Williamson, 1981) include applying for sustainability certificates and accreditation; the additional costs of sustainable products compared to less sustainable alternatives; choosing, managing and monitoring sustainable food and catering suppliers on a daily basis. In our study, these costs are absorbed by the universities in the in-house mode, whilst in the outsourced mode they are carried by the contractors. Though the University will be paying for these costs indirectly, this is often at a lower cost overall, for example: the appointed contractor may already have the required sustainability accreditations. Thus, it can be argued that these direct SP 
implementation costs are higher in the case of in-house SP, when compared with outsourced SP.

In addition to comparing the transaction costs, and the other direct costs of SP implementation, it is also argued that these relative differences in costs for the two implementation modes may only apply in the short term - as they are a direct result of the challenges as shown in Figure 1. However, in the long term, the findings suggest that the facilitators can be used to reduce some of those costs, thereby leading to supporting advantages for a particular implementation mode, which in turn address the strategic objectives related to SP. Figure 2 below illustrates this line of argument. Therefore, whilst both implementation modes have inefficiencies in terms of the total SP implementation costs in the short run, it is proposed that in both cases, there are appropriate means of becoming more sustainably efficient in the longer term:

Proposition 1: Irrespective of the choice of outsourcing and in-house implementation modes, organisations will use facilitators to try to lower their short term SP implementation costs to become more sustainably efficient in the long run.

\section{[Take in Figure 2]}

In particular, the findings suggest that the outsourcing universities aim to lower their transaction costs through building more sustainable contractor management practices including the 'collaborative relationships' and 'sustainable contract management' facilitators as discussed above. This is supported in the extant literature by Brown (2008), who also suggests that sustainable contractor management practices should include: evaluating and understanding the related sustainability issues within their contractors' processes; learning how to measure and monitor them effectively; and having a greater ability to encourage contractors in all aspects of sustainability. It is therefore concluded that our findings will apply beyond the context studied to SP more broadly and proposed that: 
Proposition 2: The SP outsourcing organisations aim to lower their transaction costs, to become more sustainably efficient in the long run, by building sustainable contractor management.

On the other hand, the findings suggest that in-house universities aim to reduce their direct SP implementation costs by 'developing in-house expertise' within their internal buyers' team. Building this expertise could include building a strong sustainability accreditation and initiatives portfolio and training catering staff to better balance the objectives of sustainability, cost and quality in their services and procurement activities. This training need may in part be addressed through 'purchasing consortium assistance', a key facilitator in this implementation mode (Figure 1). In addition, this assistance can reduce the transaction costs involved when dealing with the actual suppliers of the catering function, given the framework agreements provided by the purchasing consortiums. Whilst purchasing consortiums are not readily available to every sector, they can be argued to be a form of horizontal collaboration, which is an emerging concept in the sustainable supply chain management literature (e.g. Benstead, Hendry \& Stevenson, 2018; Touboulic \& Walker, 2015b). Thus it is argued that this conclusion can also be generalised to the broader SP context and it is proposed that:

Proposition 3: The in-house organisations aim to reduce their SP implementation costs to become more sustainably efficient in the long run by developing internal sustainability expertise aided, in part, by horizontal collaboration such as through purchasing consortium assistance.

Thus, in terms of the relative costs of the outsourcing versus in-house SP implementation mode, it is concluded that both can be cost effective in the long term, albeit by different means. The cost of switching to outsourced or in-house services would, of course, be prohibitive, and is affected by other criteria, as shown in the prior literature by authors such as Canez, Platts \& Probert (2000). Therefore, it can also be argued that it is likely in most cases 
to be important to incorporate SP into the existing implementation mode of an organisation. Finally, it is noted that these conclusions are likely to only exist where the incorporation of sustainability into procurement practices remains is in its infancy. Thus, the findings may also be relevant to the implementation of other new innovative procurement practices, and indeed new strategic priorities in general, where information asymmetries between the buyer and the contractor are likely.

\section{The application of Principal Agency Theory (PAT): Efficient Contractual Relationships}

Given the analysis of the direct and indirect costs of different modes of SP implementation presented above, PAT can be used to guide the design of the most efficient contractual relationship, not only between the university (as the principal in this case) and the contractor (the agent), but also in terms of employment based incentive schemes for in-house buyers (as the agents). A key factor that can be argued to aid in the efficient design of contractual relationships in this context is the assumption of increasing maturity of: (1) the SP implementation process; and (2) the associated knowledge of SP for both parties (Pagell, Wu \& Wasserman, 2010). In particular, it can be argued that this increased maturity can contribute in reducing the gap in information asymmetries between the university (as the principal) and the contractors/in-house buyers (as the agents). Subsequently, such increased maturity can contribute to the creation of more innovative contractual relationships. The innovative nature of this can be directly related to the type of contractual relationship, or to the implementation process specification, which is typically included in either a written agreement with a contractor or an employment-based incentive scheme. For example, for outsourcing universities, a mixed contract could be developed that is both behaviour-based and outcomebased, as suggested by Logan (2000) in the context of outsourcing transportation. A mixed contract of this type would contribute to reducing contractor risk around termination, given the 
inclusion of behaviour-based payments, whilst at the same time including incentives based on the evaluation of particular outcomes in terms of specific performance targets (e.g., $\mathrm{CO}^{2}$ emissions reduction, Social Return on Investment) (Coley, Howard \& Winter, 2008; Weber \& Matthews, 2008; Moretti, 2010; Millar \& Hall, 2013). In addition, contracts could specify aspects of the implementation process, such as the use of specific technologies or computerised operating systems that could enable the university to instantly and continuously monitor performance. Thus these more complete and innovative contractual relationships could lead to increased SP performance over time. It is therefore argued that the application of PAT leads to the following proposition:

Proposition 4: Over time, due to an increasing maturity of SP implementation processes, the principal will be better able to design improved, more efficient, complete and innovative contractual relationships between itself and its agents - leading to improvements in SP-related performance metrics.

\section{Conclusion}

This study has shown distinctive differences between in-house and outsourcing implementation modes in the pursuit of SP, even though all five of the Universities studied had similar sustainability goals. In general terms, these goals included: (i) a strong sense of social responsibility and ethical obligation - leading to a desire to lead the way in taking environmental and socially sustainable initiatives; (ii) the objective of having a competitive sustainability position by being highly ranked in the Universities Green League Table; and (iii) the willingness to meet the increased sustainability-related expectations of students, thereby improving student satisfaction. To meet these objectives, all Universities were undertaking a variety of initiatives, as summarised in Table 4. As indicated in column four of the table, some initiatives were aimed primarily at environmental sustainability (such as composting food 
waste, reusable catering equipment and using biodegradable packaging), while others were aimed primarily at social sustainability (such as meat free Mondays for customer health, buying charitable water bottles and Fair Trade accreditation); there were also initiatives aimed at both environmental and social sustainability (such as the Food for Life and Red Tractor accreditations). Whilst the set of initiatives varied slightly between the five focal Universities, the difference was not linked to whether the in-house versus outsourced implementation mode was being used. Therefore, it is concluded that the aims for SP and the initiatives undertaken do not differ significantly depending on the implementation mode. However, the approaches required to also achieve economic sustainability as needed for the TBL do differ depending on the specific implementation mode as further explained below.

In terms of the distinctive differences between the two implementation modes, the findings suggest that outsourcing Universities face the challenges of reduced control over the buyers, which in turn reduces the flexibility for introducing new SP initiatives. This brings with it relatively high transaction costs for the implementation of SP in the short term, though other direct SP implementation costs may, initially, appear to be lower. In contrast, the inhouse SP implementation mode brings higher direct costs in the short-term as Universities need to work with their suppliers to implement SP with associated greater risks - although this can be offset by lower transaction costs in terms of the relationship between the University and its own internal buyers. In the longer term, it is argued that each implementation mode could successfully implement SP. For the in-house mode, this would require greater development of in-house SP expertise; whilst for the outsourced mode, this would require building on the associated sustainability contractor management activities and ongoing collaborative relationships.

Whilst this study focuses on the implementation of SP in the food and catering services of the UK HE sector, the findings are argued to apply more broadly to organisations considering 
the make versus buy decision involving innovative practices that lead to information asymmetries. In particular, the application of PAT suggests that, over time, the increased maturity of innovative practices will enable the principal to design more complete and efficient contractual relationships between itself and its agents.

\section{Managerial Implications}

For Universities operating using the in-house mode, the research suggests that it is particularly important to capture and cultivate the sustainability passion of its employees, providing an appropriate environment for the food and catering staff to work alongside the students - thereby harnessing the enthusiasm of these important customers. This may also involve greater investment in training - aided by purchasing consortium assistance - to reduce SP implementation costs. For those operating in an outsourced mode, the key issue is to allow for evolution within contracts, to ensure that, wherever possible, the contracts positively encourage further sustainability-related innovations. The research also suggests that University managers need to be more aware of the disadvantages of the professionalism associated with outsourcing, given the inherent information asymmetry at the initial contract signing stage.

The research also has implications for managers in other sectors, who may be similarly considering the impact of using in-house versus outsourced implementation modes on SP or any other new strategic priority for which information asymmetries are likely. Therefore, the findings are relevant to any sector that has the option to outsource a function that includes a significant procurement function, or any sector with evolving priorities. In these broader contexts, the research confirms the need for managers to carefully develop efficient and effective contractual relationships, and to ensure that those relationships evolve appropriately as the maturity of the innovative practice adopted increases. 


\section{Limitations and Further Research}

Further research is needed to incorporate SP-related findings into outsourcing decision models, such as that by Canez, Platts \& Probert (2000). Sustainability could be added as a separate construct to be evaluated in these models, or could be incorporated into the existing strategic factors such as, for example, cost and performance. The four propositions presented above could also be verified through further research, for example by looking at a larger sample of Universities. In addition, this research is limited by its focus on the Universities themselves, as the focal public sector unit, and the relationship between the University as an entity and those responsible for SP in the catering function. Further research is also needed to look at how specific implementation modes affect the way in which SP practices are rolled out across the supply chain, both upstream to multiple tiers of suppliers and downstream to bring in the views of customers. Finally, additional research is needed on how to design effective and efficient contracts, between a principal and agents at different tiers of the supply chain, when the principal wishes to address important strategic objectives through the adoption of innovative practices such as SP.

\section{References}

Aastrup, J. \& Halldórsson, Á. (2008). Epistemological role of case studies in logistics: A critical realist perspective. International Journal of Physical Distribution \& Logistics Management, 38(10), 746-763.

Ackroyd, S. (2004). Methodology for management and organisation studies: some implication of critical realism. In: Fleetwood, S., Ackroyd, S. (ed.) Critical realist applications in organisation and management studies. London: Routledge.

Ageron, B., Gunasekaran, A. \& Spalanzani, A. (2012). Sustainable supply management: An empirical study. International Journal of Production Economics, 140(1), 168-182. 
Antonio, K. \& Lau, W. (2011). The implementation of social responsibility in purchasing in Hong Kong/Pearl River Delta: A case study. Strategic Outsourcing: An International Journal, 4(1), 13-46.

Ashby, A., Leat, M., \& Hudson-Smith, M. (2012). Making connections: a review of supply chain management and sustainability literature. Supply Chain Management: An International Journal. 17(5), 497-516.

Bajec, P., Tuljak-Suban, D. \& Krmac, E. (2015). Do ISO standards favour logistics provider efficiency, competitiveness and sustainability? A Slovenian perspective. The International Journal of Logistics Management, 26(2), 275-295.

Bala, A., Muñoz, P., Rieradevall, J. \& Ysern, P. (2008). Experiences with greening suppliers. The Universitat Autònoma de Barcelona. Journal of Cleaner Production, 16(15), 16101619.

Benstead A.V., Hendry L.C. \& Stevenson M., (2018) "Horizontal Collaboration in response to modern slavery legislation: An action research project", International Journal of Operations and Production Management, 38(12), 2286-2312.

Bhamra, R. (2012). Sustainable outsourcing: a practice survey and research opportunities. International Journal of Sustainable Engineering, 5(4), 304-311.

Blome, C., Hollos, D. \& Paulraj, A. (2014). Green procurement and green supplier development: antecedents and effects on supplier performance. International Journal of Production Research, 52(1), 32-49.

Brammer, S. \& Walker, H. (2011). Sustainable procurement in the public sector: an international comparative study. International Journal of Operations \& Production Management, 31(4), 452-476. 
Brewer, B. L., Ashenbaum, B. \& Carter, J. R. (2013). Understanding the Supply Chain Outsourcing Cascade: When Does Procurement Follow Manufacturing Out the Door? Journal of Supply Chain Management, 49(3), 90-110.

Brewer, B., Wallin, C. \& Ashenbaum, B. (2014). Outsourcing the procurement function: Do actions and results align with theory? Journal of Purchasing and Supply Management, 20(3), 186-194.

Brown, D. (2008). It is good to be green: Environmentally friendly credentials are influencing business outsourcing decisions. Strategic Outsourcing: An International Journal, 1(1), 8795.

Cánez, L. E., Platts, K. W. \& Probert, D. R. (2000). Developing a framework for make-or-buy decisions. International Journal of Operations \& Production Management, 20(11), 13131330.

Carter, C. R. \& Rogers, D. S. (2008). A framework of sustainable supply chain management: moving toward new theory. International Journal of Physical Distribution \& Logistics Management, 38(5), 360-387.

Chen, J. Y. \& Slotnick S. A. (2015). Supply chain disclosure and ethical sourcing. International Journal of Production Economics, 161, 17-30.

Chen, L., Zhao, X., Tang, O., Price, L., Zhang, S. \& Zhu, W. (2017) Supply chain collaboration for sustainability: A literature review and future research agenda. International Journal of Production Economics, 194, 73-87.

Coley, D., Howard, M. \& Winter, M. (2009). Local food, food miles and carbon emissions: A comparison of farm shop and mass distribution approaches. Food Policy, 34, 150-155.

Easton, G. (2010). Critical realism in case study research. Industrial Marketing Management, $39(1), 118-128$. 
Eisenhardt, K. M. (1989a). Building Theories from Case Study Research. The Academy of Management Review, 14(4), 532-550.

Eisenhardt, K.M. (1989b). Agency Theory: An Assessment and Review. The Academy of Management Review, 14, 57-74.

Eisenhardt, K. M. \& Graebner, M. E. (2007). Theory building from cases: opportunities and challenges. Academy of Management Journal, 50(1), 25-32.

Elkington, J. (1999). Cannibals with forks: The triple bottom line of $21^{\text {st }}$ century business, Oxford, Capstone.

Emiliani, M.L. (2010). Historical lessons in purchasing and supplier relationship management. Journal of Management History, 16 (1), 116-136.

Gibbert, M., Ruigrok, W. \& Wicki, B., (2008). What passes as a rigorous case study? Strategic Management Journal, 29(13), 1465-1474.

Gibbs, G. R. (2002). Qualitative data analysis: Explorations with NVivo, Buckingham; Phildelphia, Pa., Open University

Ghadge, A., Kidd, E., Bhattacharjee, A. \& Tiwari, M.K., (2019). Sustainable procurement performance of large enterprises across supply chain tiers and geographic regions. International Journal of Production Research, 57(3), 764-778.

Gimenez, C. \& Tachizawa, E. M. (2012). Extending sustainability to suppliers: a systematic literature review, Supply Chain Management: An International Journal, 17 (5), 531-543.

Glock, C. H., Grosse, E. H. \& Ries, J. M. (2017). Decision support models for supplier development: Systematic literature review and research agenda. International Journal of Production Economics, 193, 798-812.

Hoejmose, S. U. \& Adrien-Kirby, A. J. (2012). Socially and environmentally responsible procurement: A literature review and future research agenda of a managerial issue in the 21st century. Journal of Purchasing and Supply Management, 18(4), 232-242. 
Hoffmann, H., Busse, C., Bode, C. \& Henke, M. (2014). Sustainability-Related Supply Chain Risks: Conceptualization and Management, Business Strategy and the Environment, 23(3), $160-172$.

Huq, F. A., Stevenson, M. \& Zorzini, M. (2014). Social sustainability in developing country suppliers: An exploratory study in the ready made garments industry of Bangladesh. International Journal of Operations \& Production Management, 34(5), 610-638.

Jain, D. M. \& Khurana, R. (2013). Need for sustainable global business model in software outsourcing: The Indian perspective. Business Process Management Journal, 19(1), 54-69.

Jiang, B. (2009). Implementing supplier codes of conduct in global supply chains: Process explanations from theoretic and empirical perspectives. Journal of business ethics, 85(1), $77-92$.

Kelly, S., Wagner, B. \& Ramsay, J., (2018). Opportunism in buyer-supplier exchange: a critical examination of the concept and its implications for theory and practice. Production Planning \& Control, 29(12), 992-1009

Kerkfeld, D. \& Hartman E., (2012). Maximizing impact of investments into purchasing and supply management. International Journal of Physical Distribution and Logistics Management, 42 (5) (2012), 464-489.

Ketokivi, M. \& Choi, T. (2014). Renaissance of case research as a scientific method. Journal of Operations Management, 32(5), 232-240.

Kremic, T., Tukel, O. I. \& Rom, W. O. (2006). Outsourcing decision support: a survey of benefits, risks, and decision factors. Supply Chain Management: An International Journal, 11(6), 467-482.

Li, S., Okoroafo, S. \& Gammoh, B. (2014). The role of sustainability orientation in outsourcing: Antecedents, practices, and outcomes. Journal of Management and Sustainability, 4(3), 27-36. 
Logan, S.M. (2000). Using Agency Theory to Design Successful Outsourcing Relationships. The International Journal of Logistics Management, 11, 21 - 32.

Lozano, R., Lukman, R., Lozano, F. J., Huisingh, D. \& Lambrechts, W. (2013). Declarations for sustainability in higher education: Becoming better leaders, through addressing the university system. Journal of Cleaner Production, 48, 10-19.

Luthra, S., Mangla, S.K., Shankar, R., Garg, C.P., \& Jakhar, S. (2018). Modelling critical success factors for sustainability initiatives in supply chains in Indian context using GreyDEMATEL. Production Planning \& Control, 29(9), 705-728.

Macchion, L., Da Giau, A., Caniato, F., Caridi, M., Danese, P., Rinaldi, R. \& Vinelli, A. (2018). Strategic approaches to sustainability in fashion supply chain management. Production Planning \& Control, 29(1), 9-28.

Mansi, M. (2015). Sustainable procurement disclosure practices in central public sector enterprises: Evidence from India. Journal of Purchasing and Supply Management, 21(2), $125-137$.

McIvor, R. (2009). How the transaction cost and resource-based theories of the firm inform outsourcing evaluation. Journal of Operations Management, 27(1), 45-63.

McIvor, R. T., Humphreys, P. K. \& Mcaleer, W. E. (1997). A strategic model for the formulation of an effective make or buy decision. Management Decision, 35(2), 169-178.

Mendoza, J. A. \& Clemen, T. R. (2013). Outsourcing sustainability: A game-theoretic modeling approach. Environment Systems and Decisions, 33(2), 224-236.

Meredith, J. (1998). Building operations management theory through case and field research. Journal of Operations Management, 16(4), 441-454.

Miles, M. B., Huberman, A. M. \& Saldaña A, J. (2014). Qualitative data analysis: A methods sourcebook, Los Angeles, Calif., SAGE Publications Inc. 
Millar, R. \& Hall, K. (2012). Social Return on Investment (SROI) and Performance Measurement. Public Management Review, 15, 923-941.

Moosavirad, S. H., Kara, S. \& Hauschild, M. Z. (2014). Long term impacts of international outsourcing of manufacturing on sustainability. CIRP Annals - Manufacturing Technology, 63(1), 41-44.

Moretti, E. (2010). Local Multipliers. American Economic Review: Papers \& Proceedings, $100,1-7$.

National Union of Students. (2013). The living wage in the UK higher education sector. Universities UK. Available at: https://www.unison.org.uk/content/uploads/2013/11 Briefings-and-CircularsLiving-wage-research-Exec-summary3.pdf (accessed 10th March 2019).

Natukunda, C. M., Pitt, M. \& Nabil, A. (2013). Understanding the outsourcing of facilities management services in Uganda. Journal of Corporate Real Estate, 15(2), 150-158.

Oglethorpe, D. \& Heron, G. (2013). Testing the theory of constraints in UK local food supply chains. International Journal of Operations \& Production Management, 33(10), 1346-1367.

Pagell, M., Wu, Z. \& Wasserman, M. E. (2010). Thinking differently about purchasing portfolios: An assessment of sustainable sourcing. Journal of Supply Chain Management, 46(1), 57-73.

People \& Planet University League (2015) - The Tables | People \& Planet. [online] Available at: https://peopleandplanet.org/university-league/2015/tables (accessed 27 ${ }^{\text {th }}$ April 2016).

Preuss, L. (2009). Ethical sourcing codes of large UK-based corporations: Prevalence, content, limitations. Journal of Business Ethics, 88 (4), 735-747.

Sanderson, J., Losdale, C., Mannion, R. \& Matharu, T. (2015). Towards a framework for enhancing procurement and supply chain management practice in the NHS: lessons for 
managers and clinicians from a synthesis of the theoretical and empirical literature. Health Services and Delivery Research, 3, 1-136.

Sayed M., Hendry L.C., \& Zorzini Bell M. (2017). "Institutional Complexity and Sustainable Supply Chain Management Practices”, Supply Chain Management: An International Journal, 22 (6), 542-563.

Seuring, S. \& Müller, M. (2008). From a literature review to a conceptual framework for sustainable supply chain management. Journal of Cleaner Production, 16(15), 1699-1710.

Suyabatmaz, A., Altekin, T. F. \& Sahin, G. (2014). Hybrid simulation-analytical modelling approaches for the reverse logistics network design of a third-party logistics provider. Computers \& Industrial Engineering, 70, 74-89.

Tate, W. L., Dooley, K. J. \& Ellram, L. M. (2011). Transaction cost and institutional drivers of supplier adoption of environmental practices. Journal of Business Logistics, 32(1), 6-16.

Touboulic, A. \& Walker, H. (2015a). Theories in sustainable supply chain management: a structured literature review. International Journal of Physical Distribution \& Logistics Management, 45(1/2), 16-42.

Touboulic, A. and Walker, H., (2015b). Love me, love me not: A nuanced view on collaboration in sustainable supply chains. Journal of Purchasing and Supply Management, $21(3), 178-191$.

Ulbrich, F. \& Schulz, V. (2014). Seven challenges management must overcome when implementing IT-shared services. Strategic Outsourcing: An International Journal, 7(2), 94-106.

Universities UK., (2013). Working for a smarter, stronger sector: Efficiency and effectiveness in higher education progress report. [online] Universities UK. Available at: https://www.universitiesuk.ac.uk/policy-and-analysis/reports/Documents/2013/workingfor-a-smarter-stronger-sector.pdf $\left(\right.$ accessed 14 ${ }^{\text {th }}$ May, 2109). 
ac.uk/highereducation/Documents/2013/WorkingForAsmarterStrongerSector.pdf $>$

Voss, C., Johnson, M. \& Godsell, J., (2016). Case Research. In: Karlsson, C. (Ed), Research Methods for Operations Management, $2^{\text {nd }}$ Edition, Routledge, New York, 165-197.

Walker, H. \& Brammer, S. (2012). The relationship between sustainable procurement and eprocurement in the public sector. International Journal of Production Economics, 140(1), $256-268$.

Walker, H. \& Brammer, S. (2009). Sustainable procurement in the United Kingdom public sector. Supply Chain Management, 14(2), 128-137.

Walker, H. \& Preuss, L. (2008). Fostering sustainability through sourcing from small businesses: Public sector perspectives. Journal of Cleaner Production, 16(15), 1600-1609.

Wang, E. T. G. (2002). Transaction attributes and software outsourcing success: An empirical investigation of transaction cost theory. Information Systems Journal, 12(2), 153-181.

Weber, C. L. \& Matthews, H. S. (2008). Food-Miles and the Relative Climate Impacts of Food Choices in the United States. Environmental Science \& Technology, 42, 3508-3513.

Wilhelm, M., Blome, C., Weick, E. \& Xiao, C.Y. (2016). Implementing sustainability in multitier supply chains: Strategies and contingencies in managing sub-suppliers. International Journal of Production Economics, 182, 196-212.

Williamson, O. E. (2008). Outsourcing: Transaction cost economics and supply chain management. Journal of Supply Chain Management, 44(2), 5-16.

Williamson, O. E. (1981). The economics of organization: The transaction cost approach. American Journal of Sociology, 87(3), 548-577.

Yawar, S.A. \& Seuring S. (2017). Management of Social Issues in Supply Chains: A literature Review Exploring Social Issues, Actions and Performance Outcomes. Journal of Business Ethics, 141, 621-643.

Yin, R. K. (2018). Case st.udy research and applications: Design and methods, Los Angeles, Calif., Sage Publications, $6^{\text {th }}$ edition, ISBN-10: 1506336167. 
Young, S., Nagpal, S. \& Adams, C. A. (2015). Sustainable procurement in Australian and UK Universities. Public Management Review, 18(7), 993-1016.

Zhang, M., Pawar, K.S. \& Bhardwaj, S. (2017). Improving supply chain social responsibility through supplier development. Production Planning \& Control, 28(6-8), 500-511.

Zorzini, M., Hendry, L.C., Huq, F.A. \& Stevenson, M., (2015). Socially responsible sourcing: reviewing the literature and its use of theory. International Journal of Operations \& Production Management, 35(1), 60-109.

\section{Appendix: Interview Questionnaire Scripts}

\section{A: Interview Questions for In-House Universities}

1- What are the current sustainability initiatives (environmental \& social initiatives) that you are implementing in the food and catering procurement section?

2- Why have these initiatives been selected?

3- What are the main pressures and drivers behind having a sustainable food and catering services?

4- How have the buyers been involved in the development of these initiatives? Were any training programmes necessary?

5- Did you experience any resistance or difficulty from your buyers towards implementation of these initiatives? If yes, how did you deal with it?

6- Do you have any principles/guidelines/criteria to use when making difficult decisions on which supplier to use? (e.g. choosing between a green/expensive supplier and a cheaper less sustainable alternative)? If not, do you think that some guidelines would be useful?

7- Can you describe the general process that you use for selecting your suppliers?

8- How is sustainability being incorporated into selecting your suppliers as well as into tenders' events? And what are the tools being used in that (e.g. Self-assessment questionnaire, visiting suppliers' factories, etc)?

9- How do you measure the success of these initiatives (e.g. \% of sustainable purchases)? Do you have any data on this as yet?

10- What is the impact of these sustainable initiatives on financial performance of the university/procurement department in the short-term/long-term? Would you please give us some numerical examples?

11- What are the enablers that help in the implementation of your sustainability agenda? 
12- What are the challenges or barriers that hinder the implementation or success of your sustainability agenda?

\section{B: Interview Questions for Outsourcing Universities}

1- Would you please give us an overview about your food and catering services?

2- What are the main reasons of outsourcing the food and catering services? And have you had in-house catering services before?

3- Can you describe the general process that you use for selecting your outsourcing companies?

4- What is the nature of the contract with the outsourcing companies?

5- How is sustainability being incorporated into selecting the suppliers as well as into tenders' events? And what are the tools being used in that (e.g. Self-assessment questionnaire, visiting suppliers' factories, etc)?

6- What are the advantages and disadvantages (challenges) that you face in outsourcing food and catering services?

7- What are the current sustainability initiatives (environmental \& social initiatives) that you are implementing in the food and catering procurement section through your outsourcing companies?

8- Why have these initiatives been selected?

9- What are the main pressures and drivers behind having a sustainable food and catering services?

10- How have the university been involved in these initiatives if they are implemented through the outsourcing companies?

11- Did you experience any resistance or difficulty from your outsourcing companies towards implementation of these initiatives? If yes, how did you deal with it?

12- How do you measure the success of these initiatives? Do you have any data on this as yet?

13- What is the impact of these sustainable initiatives on financial performance of the university/procurement department in the short-term/long-term? Would you please give us some numerical examples?

14- What are the enablers that help in the implementation of your sustainability agenda?

15- What are the challenges or barriers that hinder the implementation or success of your sustainability agenda?

16- Do you have influence upon your outsourcing companies regarding their sustainability practices? And if yes, what is the degree and the extent of this influence across the supply chain? And how do you exert influence?

17- Do you have influence upon your outsourcing companies regarding their prices? And how do you negotiate prices with them?

18- To what extent do you communicate and share information with your outsourcing companies regarding sustainability initiatives? And do you think that this is considered an important factor in the successful implementation of sustainability initiatives? 
19- How do you continuously monitor your outsourcing companies and their supply chain sustainability practices? What are the difficulties, if there are any, that you face in monitoring them?

20 - Are there any other ways in which you motivate your outsourcing companies and their supply chain to continue to be sustainable?

\section{C: Interview Questions for Contractors}

1- Would you please give us a brief overview about your company?

2- From your opinion, what is the reason that pushes the universities to outsource their food and catering services?

3- What sustainability initiatives (environmental, social and economic) are you implementing or try to implement in your business?

4- If none, then: Are sustainability issues growing in importance in your business, and do you expect to implement initiatives in the future?

5- What are the pressures and drivers behind the implementation of your current or potential sustainability initiatives?

6- Who are your stakeholders that you are aiming to please or satisfy through your current or potential sustainability initiatives?

7- What are the enablers that help you in the implementation of your sustainability agenda?

8- What are the challenges or barriers that hinder the implementation or success of your sustainability agenda?

9- Would you please give us a brief overview about the different types of business models in the relationship with the universities?

10- For how long have you been working with this University and what type of contract or business model do you have with it?

11- What are the main sustainability requirements (environmental and social) that are required from the universities and is that included in your contract with them or required on an informal, verbal basis? (These requirements may be related to the supplied products or in your business processes)? Please can you provide examples?

12- Are these requirements compulsory for you? And what would happen if you couldn't meet them?

13- What can you easily meet from these requirements and what are considered a challenge for you?

14- Do you feel any other pressures or influence from the universities towards your sustainability practices? If yes, how do you experience that?

15- How do you set your prices and do you feel any pressures from the universities towards your prices? If yes, how do you experience that and deal with it?

16- Which information do you need to share (from both directions) with the universities regarding sustainability practices to help you in meeting their requirements? And are you satisfied with the current level of information sharing?

17-Do you expect any help, development or consultation from the universities to improve your sustainability practices and capabilities? 
18- What advantages might the universities sustain by developing or supporting your sustainability capabilities (give examples)?

\section{D: Interview Questions for Purchasing Consortiums}

1- What services does the consortium offer to its partners and what are its strategic objectives?

2- How is the consortium seeing sustainability in buying practices?

3- What are the aspects of sustainability that the consortium focuses on (Environmental, Social and Economic)? And how do you see the interaction between them?

4- What are the pressures and drivers that the consortium is experiencing to encourage HE institutions to incorporate sustainability in their buying practices? And do they differ from what HE institutions themselves are experiencing.

5- Who are the stakeholders that the consortium tries to please regarding their sustainable buying practices? And do they differ from HE institutions stakeholders.

6- How many members (universities, colleges, other institutions) do the consortium have? And how they are distributed across the UK?

7- How would you describe the relationship between the consortium and its partners (universities)?

8- What are the benefits that you provide for your partners in terms of buying practices in general, and sustainability in particular?

9- How do you encourage or support your partners to implement sustainability practices in their buying practices (e.g. training courses, consultancy support ... etc)? And does that support remain if they don't buy from your framework's suppliers?

10- Do you have any kind of influence upon your partners' sustainability practices? And what are the difficulties that you face with them regarding sustainability practices?

11- Do you have any partnership or relationship with any other consortiums? And how can you share best practices with other consortiums?

12- Would you please give us an overview about the suppliers included in the framework (their numbers, categories, sizes, locations ... etc)?

13- Can you describe the general process that you use for selecting these suppliers?

14- What is the nature of the contract with the suppliers included in the framework?

15 - How is sustainability being incorporated into selecting your framework's suppliers as well as into tenders' events? And what are the tools being used in that (e.g. Selfassessment questionnaire, visiting suppliers' factories, etc)? 


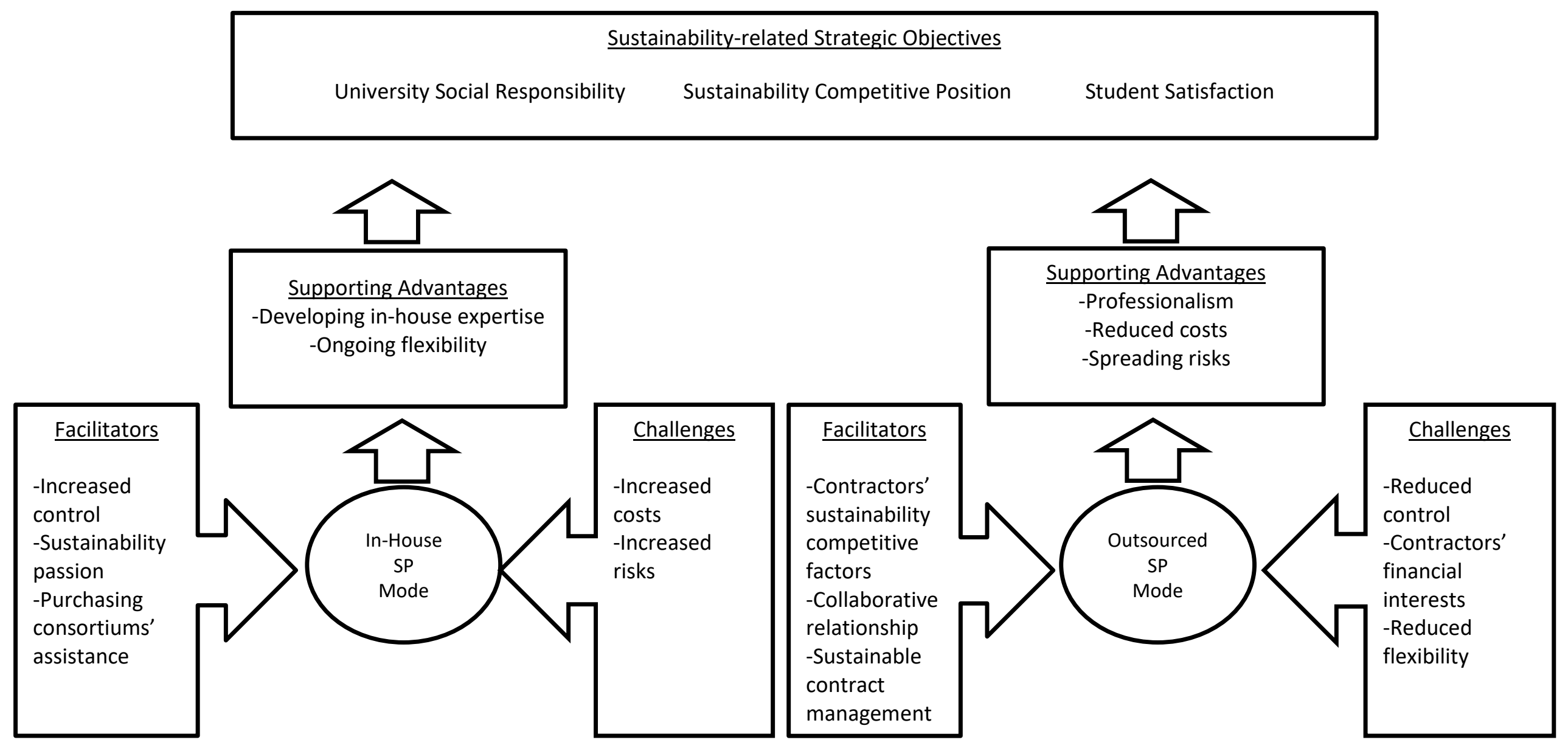

FIGURE 1: Proposed Conceptual Model for Outsourcing vs In-house SP Implementation Modes 
Time

Scale

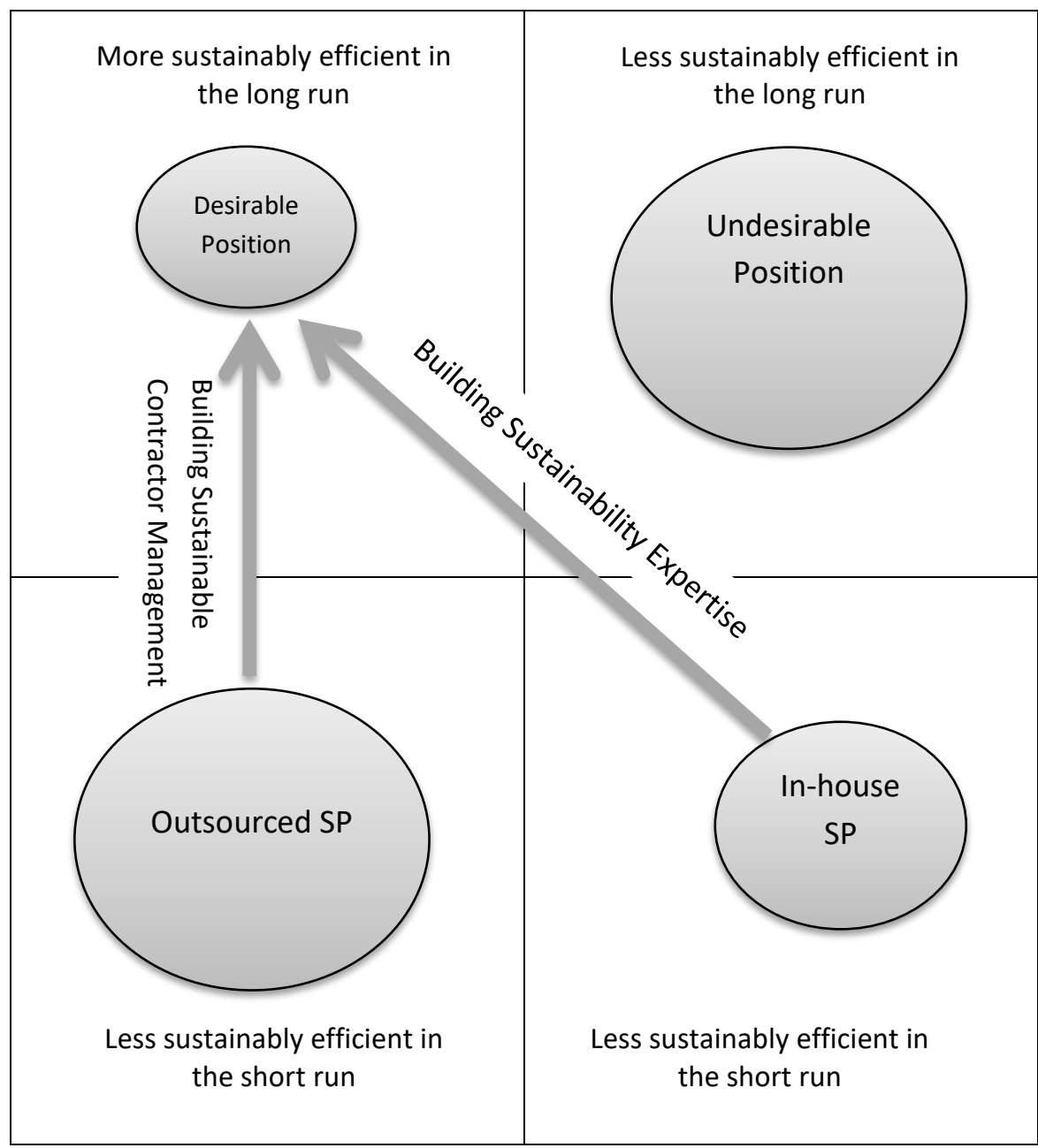

Low

Other SP Implementation Costs

High

Transaction Costs

FIGURE 2: Relative Costs of the In-house versus Outsourced SP

Implementation Modes 
TABLE 1: Case Selection Criteria for the Five Focal HE Institutions

\begin{tabular}{|c|c|c|c|c|}
\hline University & $\begin{array}{c}\text { In-House / } \\
\text { Outsourcing }\end{array}$ & $\begin{array}{c}\text { Sustainability } \\
\text { Performance }\end{array}$ & $\begin{array}{c}\text { City Size } \\
\text { (population) }\end{array}$ & Region \\
\hline FHE1 & In-House & Second Class & $<150,000$ & North West \\
\hline FHE2 & In-House & Second Class & 500,000 & North West \\
\hline FHE3 & In-House & First Class & $<150,000$ & London \\
\hline FHE4 & Outsourcing & First Class & $>8$ million & London \\
\hline FHE5 & Outsourcing & First Class & $>8$ million & \\
\hline
\end{tabular}


TABLE 2: Conducted Interviews

\begin{tabular}{|c|c|c|c|c|c|c|}
\hline Abbreviation & $\begin{array}{l}\text { Nature of } \\
\text { the Business }\end{array}$ & $\begin{array}{c}\text { Product and } \\
\text { Services }\end{array}$ & $\begin{array}{l}\text { Position } \\
\text { in the } \\
\text { Supply } \\
\text { Chain }\end{array}$ & $\begin{array}{l}\text { Position of } \\
\text { Interviewee }\end{array}$ & $\begin{array}{c}\text { Number } \\
\text { of } \\
\text { Interviews }\end{array}$ & $\begin{array}{l}\text { Reference } \\
\text { Mnemonic }\end{array}$ \\
\hline \multirow{4}{*}{ FHE1 } & \multirow{4}{*}{ University } & \multirow{4}{*}{$\begin{array}{l}\text { Higher } \\
\text { Education } \\
\text { Services } \\
\text { (In-House } \\
\text { Catering) }\end{array}$} & \multirow{4}{*}{$\begin{array}{l}\text { Focal } \\
\text { Company }\end{array}$} & $\begin{array}{l}\text { Procurement } \\
\text { Manager }\end{array}$ & 1 & FHE1-I1 \\
\hline & & & & $\begin{array}{c}\text { Food } \\
\text { Operations } \\
\text { Manager }\end{array}$ & 1 & FHE1-I2 \\
\hline & & & & $\begin{array}{l}\text { Executive } \\
\text { Head Chef }\end{array}$ & 1 & FHE1-I3 \\
\hline & & & & $\begin{array}{l}\text { Project Team } \\
\text { Leader }\end{array}$ & 2 & FHE1-I4 \\
\hline \multirow[t]{2}{*}{ FHE2 } & \multirow[t]{2}{*}{ University } & \multirow{2}{*}{$\begin{array}{l}\text { Higher } \\
\text { Education } \\
\text { Services } \\
\text { (In-House } \\
\text { Catering) }\end{array}$} & \multirow{2}{*}{$\begin{array}{l}\text { Focal } \\
\text { Company }\end{array}$} & $\begin{array}{c}\text { Head of } \\
\text { Hospitality \& } \\
\text { Events } \\
\end{array}$ & 1 & FHE2-I1 \\
\hline & & & & $\begin{array}{l}\text { Executive } \\
\text { Head Chef }\end{array}$ & 1 & FHE2-I2 \\
\hline \multirow[t]{2}{*}{ FHE3 } & \multirow[t]{2}{*}{ University } & \multirow{2}{*}{$\begin{array}{l}\text { Higher } \\
\text { Education } \\
\text { Services } \\
\text { (In-House } \\
\text { Catering) } \\
\end{array}$} & \multirow{2}{*}{$\begin{array}{l}\text { Focal } \\
\text { Company }\end{array}$} & $\begin{array}{l}\text { Catering } \\
\text { Services } \\
\text { Manager }\end{array}$ & 1 & FHE3-I1 \\
\hline & & & & $\begin{array}{c}\text { Conference } \\
\text { Officer }\end{array}$ & 1 & FHE3-I2 \\
\hline \multirow[b]{2}{*}{ FHE4 } & \multirow[b]{2}{*}{ University } & \multirow{2}{*}{$\begin{array}{l}\text { Higher } \\
\text { Education } \\
\text { Services } \\
\text { (Outsourced } \\
\text { Catering) }\end{array}$} & \multirow[b]{2}{*}{$\begin{array}{c}\text { Focal } \\
\text { Company }\end{array}$} & $\begin{array}{c}\text { Procurement } \\
\text { Officer }\end{array}$ & 1 & FHE4-I1 \\
\hline & & & & $\begin{array}{c}\text { Head of } \\
\text { Catering and } \\
\text { Conferences } \\
\text { Services }\end{array}$ & 1 & FHE4-I2 \\
\hline \multirow[t]{2}{*}{ FHE5 } & \multirow[t]{2}{*}{ University } & \multirow{2}{*}{$\begin{array}{c}\text { Higher } \\
\text { Education } \\
\text { Services } \\
\text { (Outsourced } \\
\text { Catering) } \\
\end{array}$} & \multirow{2}{*}{$\begin{array}{c}\text { Focal } \\
\text { Company }\end{array}$} & $\begin{array}{c}\text { Procurement } \\
\text { Category } \\
\text { Manager } \\
\end{array}$ & 1 & FHE5-I1 \\
\hline & & & & $\begin{array}{c}\text { Environmental } \\
\text { Officer }\end{array}$ & 1 & FHE5-I2 \\
\hline $\mathrm{PC} 1$ & $\begin{array}{l}\text { Food and } \\
\text { Catering } \\
\text { Consortium }\end{array}$ & $\begin{array}{l}\text { Procurement } \\
\text { Professional } \\
\text { Services, } \\
\text { Suppliers } \\
\text { Frameworks }\end{array}$ & $\begin{array}{c}\text { In between } \\
\text { universities } \\
\text { (In-House } \\
\text { Catering) } \\
\text { and } \\
\text { suppliers } \\
\end{array}$ & $\begin{array}{l}\text { Chief } \\
\text { Operating } \\
\text { Officer }\end{array}$ & 1 & $\mathrm{PC} 1$ \\
\hline $\mathrm{PC} 2$ & $\begin{array}{l}\text { Food and } \\
\text { Catering } \\
\text { Consortium }\end{array}$ & $\begin{array}{l}\text { Procurement } \\
\text { Professional } \\
\text { Services, } \\
\text { Suppliers } \\
\text { Frameworks }\end{array}$ & $\begin{array}{c}\text { In between } \\
\text { universities } \\
\text { (In-House } \\
\text { Catering) } \\
\text { and } \\
\text { suppliers }\end{array}$ & $\begin{array}{l}\text { Specialist } \\
\text { Adviser }\end{array}$ & 1 & $\mathrm{PC} 2$ \\
\hline Con1 - FHE4 & $\begin{array}{l}\text { Food and } \\
\text { Catering } \\
\text { Contractor }\end{array}$ & $\begin{array}{l}\text { Food and } \\
\text { Catering } \\
\text { Services }\end{array}$ & $\begin{array}{l}\text { In between } \\
\text { the } \\
\text { University } \\
\text { and } \\
\text { suppliers } \\
\end{array}$ & $\begin{array}{c}\text { Head of } \\
\text { Sustainability } \\
\text { Business }\end{array}$ & 1 & Con1 \\
\hline Con2 - FHE5 & $\begin{array}{l}\text { Catering and } \\
\text { Facilities } \\
\text { Management } \\
\text { Contractor }\end{array}$ & $\begin{array}{l}\text { Catering and } \\
\text { Facilities } \\
\text { Management } \\
\text { Services }\end{array}$ & $\begin{array}{c}\text { In between } \\
\text { the } \\
\text { University } \\
\text { and } \\
\text { suppliers }\end{array}$ & $\begin{array}{l}\text { Contract } \\
\text { Director }\end{array}$ & 1 & Con2 \\
\hline \multicolumn{5}{|l|}{ Total } & \multicolumn{2}{|c|}{17} \\
\hline
\end{tabular}


TABLE 3: Validity and Reliability Issues Addressed Throughout the Course of the Research ${ }^{\text {a }}$

\begin{tabular}{|c|c|c|c|c|}
\hline \multirow{2}{*}{$\begin{array}{l}\text { Reliability / Validity } \\
\text { Criterion }\end{array}$} & \multicolumn{4}{|c|}{ Research Phase } \\
\hline & Design & Case Selection & Data Gathering & Data Analysis \\
\hline $\begin{array}{l}\text { Reliability } \\
\text { (demonstrating that } \\
\text { the operations can be } \\
\text { repeated with the } \\
\text { same results) }\end{array}$ & $\begin{array}{l}\text { - Developed a case study protocol } \\
\text { - Development and use of case } \\
\text { study database, facilitated with } \\
\text { NVivo }\end{array}$ & $\begin{array}{l}\text { - Clear inclusion of universities } \\
\text { that use the in-house } \\
\text { implementation mode versus } \\
\text { the outsourcing mode for SP }\end{array}$ & $\begin{array}{l}\text { Semi-structured interview } \\
\text { guidelines reported in the } \\
\text { interview protocol }\end{array}$ & $\begin{array}{l}\text { - Involvement of authors who } \\
\text { have not been in the field } \\
\text { gathering data } \\
\text { - Rigorous coding process, firstly } \\
\text { open coding, and secondly using } \\
\text { the TCE and PAT theoretical } \\
\text { lenses }\end{array}$ \\
\hline $\begin{array}{l}\text { Internal Validity } \\
\text { (establishing a causal } \\
\text { relationship whereby } \\
\text { certain conditions are } \\
\text { believed to lead to } \\
\text { other conditions) }\end{array}$ & - $n / a$ & - $\mathrm{n} / \mathrm{a}$ & $\begin{array}{l}\text { - Multiple respondents } \\
\text { - Most knowledgeable, key } \\
\text { informants interviewed } \\
\text { - Interviews transcribed, leading } \\
\text { to } 161 \text { pages of interview data, } \\
\text { and sent to interviewees for } \\
\text { validation and authenticity } \\
\text { checking }\end{array}$ & $\begin{array}{l}\text { - Pattern matching within and } \\
\text { among the cases } \\
\text { - Triangulation of data between } \\
\text { interview data, observations and } \\
\text { secondary data } \\
\text { - Discussion between authors to } \\
\text { agree coding }\end{array}$ \\
\hline $\begin{array}{l}\text { Construct Validity } \\
\text { (establishing correct } \\
\text { operational measures } \\
\text { for the concepts being } \\
\text { studied) }\end{array}$ & $\begin{array}{l}\text { - Adoption of questions linked to } \\
\text { extant SP literature }\end{array}$ & - $\mathrm{n} / \mathrm{a}$ & $\begin{array}{l}\text { - Multiple sources of information } \\
\text { - interviews, observations and } \\
\text { secondary data; } \\
\text { - Multiple interviews for focal } \\
\text { organisations; } \\
\text { - Inclusion of purchasing } \\
\text { consortium and catering } \\
\text { contractor interviewees }\end{array}$ & $\begin{array}{l}\text { Data triangulation between } \\
\text { interview data, observations and } \\
\text { secondary data } \\
\text { - Preliminary data analysis after } \\
\text { first and second stages of data } \\
\text { collection to be receptive to new } \\
\text { results }\end{array}$ \\
\hline $\begin{array}{l}\text { External Validity } \\
\text { (establishing whether } \\
\text { and how a case study's } \\
\text { findings can be } \\
\text { generalised) }\end{array}$ & $\begin{array}{l}\text { - Adoption of TCE and PAT for } \\
\text { 'Theory Suggesting and } \\
\text { Explanation' (Zorzini et al., 2015) } \\
\text { - Comparative multiple case } \\
\text { studies }\end{array}$ & $\begin{array}{l}\text { - Theoretical sampling using } \\
\text { replication logic - both literal } \\
\text { replication and theoretical } \\
\text { replication }\end{array}$ & $\begin{array}{l}\text { - Gathering data on the case } \\
\text { contexts }\end{array}$ & $\begin{array}{l}\text { - Pattern matching rather than } \\
\text { statistical projections used } \\
\text { - Comprehensive intra-case } \\
\text { analysis } \\
\text { - Consideration of case context }\end{array}$ \\
\hline
\end{tabular}

${ }^{a}$ Based on Yin (2018); Gibbert, Ruigrok \& Wicki (2008) 
TABLE 4: Sustainability Initiatives in the Cases

\begin{tabular}{|c|c|c|c|c|c|c|c|c|}
\hline Categories & Initiatives & Examples of Sustainability Concerns & $\begin{array}{c}\text { Environmental/Social } \\
\text { Impact }\end{array}$ & FHE1 & FHE2 & FHE3 & FHE4 & FHE5 \\
\hline \multirow[t]{2}{*}{ Sourcing } & Local Buying & $\begin{array}{l}\text { Helping local community and economy, } \\
\text { creating more local jobs, reducing food } \\
\text { miles }\end{array}$ & Both (mainly social) & $\sqrt{ }$ & $\sqrt{ }$ & $\sqrt{ }$ & $\sqrt{ }$ & \\
\hline & $\begin{array}{l}\text { Campus Edible } \\
\text { Farms }\end{array}$ & $\begin{array}{l}\text { Growing healthy and organic produce, } \\
\text { engaging students and staff, using } \\
\text { environmentally friendly agricultural } \\
\text { techniques }\end{array}$ & Both (mainly social) & $\sqrt{ }$ & & & & $\sqrt{ }$ \\
\hline \multirow[t]{8}{*}{$\begin{array}{c}\text { Food and } \\
\text { catering } \\
\text { Accreditations }\end{array}$} & Food for Life & $\begin{array}{l}\text { Trusty, fresh and local food, customers' } \\
\text { health, sourcing environmentally } \\
\text { sustainable and ethical food }\end{array}$ & Both (mainly social) & $\sqrt{ }$ & $\sqrt{ }$ & & $\sqrt{ }$ & $\sqrt{ }$ \\
\hline & Red Tractor & $\begin{array}{l}\text { Trusty and traceable food for customers' } \\
\text { health, animal welfare }\end{array}$ & Both (mainly social) & $\sqrt{ }$ & $\sqrt{ }$ & $\sqrt{ }$ & $\sqrt{ }$ & \\
\hline & Fair-Trade & $\begin{array}{l}\text { Helping and ensuring fair deals for } \\
\text { producers in poor and developing } \\
\text { countries }\end{array}$ & Social & $\sqrt{ }$ & $\sqrt{ }$ & $\sqrt{ }$ & $\sqrt{ }$ & $\sqrt{ }$ \\
\hline & $\begin{array}{l}\text { Marine } \\
\text { Stewardship } \\
\text { Council Fish }\end{array}$ & $\begin{array}{l}\text { Reducing over fishing to maintain future } \\
\text { fishing stock }\end{array}$ & Environmental & $\sqrt{ }$ & $\sqrt{ }$ & $\sqrt{ }$ & $\sqrt{ }$ & $\sqrt{ }$ \\
\hline & $\begin{array}{l}\text { Good Dairy \& } \\
\text { Good Egg Award }\end{array}$ & Animal welfare, customers' health & Both & & $\sqrt{ }$ & $\sqrt{ }$ & & \\
\hline & Food for the Brain & $\begin{array}{l}\text { Raising awareness of the importance of } \\
\text { optimum nutrition in mental health } \\
\text { (customers' health) }\end{array}$ & Social & & & & $\sqrt{ }$ & \\
\hline & $\begin{array}{l}\text { Vegetarian } \\
\text { Society }\end{array}$ & $\begin{array}{l}\text { Influencing, inspiring and supporting } \\
\text { people to embrace and maintain a } \\
\text { vegetarian lifestyle (customers' health) }\end{array}$ & Social & & & & $\sqrt{ }$ & \\
\hline & $\begin{array}{l}\text { Sustainable Fish } \\
\text { City }\end{array}$ & $\begin{array}{l}\text { Involvement in the campaign to have cities } \\
\text { where sustainable fish is served and } \\
\text { promoted (environmental benefits and } \\
\text { customers' health) }\end{array}$ & Both & & & & & $\sqrt{ }$ \\
\hline
\end{tabular}




\begin{tabular}{|c|c|c|c|c|c|c|c|c|}
\hline & Food Legacy & $\begin{array}{l}\text { Involvement in the campaign to build a } \\
\text { stronger, more sustainable food buying } \\
\text { and catering industry that will be a legacy } \\
\text { of the London } 2012 \text { Olympic and } \\
\text { Paralympic Games (environmental and } \\
\text { social benefits) }\end{array}$ & Both & & & & & $\sqrt{ }$ \\
\hline \multirow[t]{4}{*}{ Healthy Food } & $\begin{array}{l}\text { Organic Milk and } \\
\text { Food }\end{array}$ & $\begin{array}{l}\text { Environmentally friendly agriculture, } \\
\text { animal welfare, customers' health }\end{array}$ & Both & $\sqrt{ }$ & $\sqrt{ }$ & & $\sqrt{ }$ & $\sqrt{ }$ \\
\hline & Seasonal Menus & $\begin{array}{l}\text { Environmentally friendly agriculture, } \\
\text { reducing food miles, customers' health }\end{array}$ & $\begin{array}{l}\text { Both (mainly } \\
\text { environmental) }\end{array}$ & $\sqrt{ }$ & $\sqrt{ }$ & & $\sqrt{ }$ & \\
\hline & Free Range Egg & Animal welfare, customers' health & Both & $\sqrt{ }$ & & $\sqrt{ }$ & $\sqrt{ }$ & $\sqrt{ }$ \\
\hline & $\begin{array}{l}\text { Meat Free } \\
\text { Mondays }\end{array}$ & Customers' health & Social & & $\sqrt{ }$ & $\sqrt{ }$ & & $\sqrt{ }$ \\
\hline \multirow{6}{*}{$\begin{array}{l}\text { Waste, Recycling } \\
\text { and Energy } \\
\text { Savings }\end{array}$} & $\begin{array}{l}\text { Recycling } \\
\text { Cooking Oil }\end{array}$ & Environmental benefits, creating local jobs & $\begin{array}{l}\text { Both (mainly } \\
\text { environmental) }\end{array}$ & $\sqrt{ }$ & $\sqrt{ }$ & $\sqrt{ }$ & $\sqrt{ }$ & \\
\hline & $\begin{array}{l}\text { Recycling } \\
\text { Catering } \\
\text { Equipment }\end{array}$ & Environmental benefits, creating local jobs & $\begin{array}{l}\text { Both (mainly } \\
\text { environmental) }\end{array}$ & $\sqrt{ }$ & $\sqrt{ }$ & $\sqrt{ }$ & $\sqrt{ }$ & $\sqrt{ }$ \\
\hline & $\begin{array}{l}\text { Reusable catering } \\
\text { Equipment }\end{array}$ & Environmental benefits & Environmental & $\sqrt{ }$ & $\sqrt{ }$ & $\sqrt{ }$ & $\sqrt{ }$ & $\sqrt{ }$ \\
\hline & $\begin{array}{l}\text { Buying } \\
\text { Biodegradable } \\
\text { Packaging }\end{array}$ & Environmental benefits & Environmental & & $\sqrt{ }$ & & $\sqrt{ }$ & \\
\hline & $\begin{array}{l}\text { Composting Food } \\
\text { Waste }\end{array}$ & Environmental benefits & Environmental & & & & $\sqrt{ }$ & \\
\hline & $\begin{array}{l}\text { Discount for } \\
\text { Reusable } \\
\text { Customers' Cups }\end{array}$ & $\begin{array}{l}\text { Environmental benefits (including } \\
\text { reducing cup sourcing), encouraging } \\
\text { sustainable behaviours }\end{array}$ & $\begin{array}{l}\text { Both (mainly } \\
\text { environmental) }\end{array}$ & & & & & $\sqrt{ }$ \\
\hline \multirow[t]{3}{*}{$\begin{array}{c}\text { Water } \\
\text { Management }\end{array}$} & Tap Water & $\begin{array}{l}\text { Environmental benefits, encouraging } \\
\text { sustainable behaviours }\end{array}$ & $\begin{array}{l}\text { Both (mainly } \\
\text { environmental) }\end{array}$ & & $\sqrt{ }$ & $\sqrt{ }$ & $\sqrt{ }$ & \\
\hline & $\begin{array}{l}\text { Environmental } \\
\text { Tax on Plastic } \\
\text { Bottles }\end{array}$ & $\begin{array}{l}\text { Environmental benefits (including } \\
\text { reducing plastic bottles sourcing), } \\
\text { encouraging sustainable behaviours }\end{array}$ & $\begin{array}{l}\text { Both (mainly } \\
\text { environmental) }\end{array}$ & & & & $\sqrt{ }$ & \\
\hline & $\begin{array}{l}\text { Buying Charitable } \\
\text { Water Bottles }\end{array}$ & Social benefits & Social & & $\sqrt{ }$ & & & \\
\hline
\end{tabular}


TABLE 5: Constructs, Sub-Constructs and Sample Quotes

\begin{tabular}{|c|c|c|c|}
\hline Constructs & Sub-Construct & Sample Quotes & $\begin{array}{l}\text { Most Used Keywords } \\
\text { (all quotes) }\end{array}$ \\
\hline \multirow{4}{*}{$\begin{array}{l}\text { Sustainability-related } \\
\text { Strategic Objectives } \\
\text { [The main objectives/ } \\
\text { concerns that the } \\
\text { universities aim to } \\
\text { address through } \\
\text { implementing } \\
\text { sustainability } \\
\text { initiatives] }\end{array}$} & $\begin{array}{l}\text { University Social Responsibility } \\
\text { [The social responsibility and } \\
\text { ethical obligation that the } \\
\text { universities feel towards their } \\
\text { environment, communities and } \\
\text { general public] }\end{array}$ & $\begin{array}{l}\text {-We are educating the future and we want to educate them not just in the class room, it's } \\
\text { about how they interact with everything else, so it is our responsibility to make sure that } \\
\text { whatever we are doing whenever possible we do in the right way. (FHE2-II) } \\
\text {-We should be seen as a benchmark, we should be seen as the role model for local } \\
\text { businesses, .... we are a major public sector organisation ..., we should be at the } \\
\text { forefront in terms of initiatives like this. (FHE3-I1) } \\
\text {-Catering is one of the areas in the university where we can support the local community } \\
\text { as well (FHE1-II) }\end{array}$ & $\begin{array}{l}\text { Local, Responsibility, } \\
\text { Policy, KPI, Internal }\end{array}$ \\
\hline & $\begin{array}{l}\text { Sustainability Competitive Position } \\
\text { [The aim to achieve a high ranking } \\
\text { in the Universities' Green League } \\
\text { Table in recognition of a strong } \\
\text { competitive position, and to } \\
\text { compete effectively with high street } \\
\text { outlets] }\end{array}$ & $\begin{array}{l}\text {-A lot of our peers are doing well in sustainability so you have a green league and we } \\
\text { were quite far down in the green league at one point and then became near the top } \\
\text { universities for a year or two. ... Getting higher points in the green league is our goal, } \\
\text {... we were quite close to the bottom and that was seen as being quite embarrassing. } \\
\text { (FHE4-I2) } \\
\text {-Our members say we need to get a high rank and position in those things (e.g., Green } \\
\text { League Table) because that will affect students' decision when they make the choices } \\
\text { and compare between the universities. (PC1) } \\
\text { - When you see the initiatives people like Costa with the Costa foundation, you've got } \\
\text { Starbucks with a foundation - their charitable arm, you've got the work that's done by } \\
\text { McDonald's - they follow McDonald's HTV down the road and all their beef is British, } \\
\text { all the oil that they use they recycle and reuse, ... You have to look and say that all these } \\
\text { organisations are driving these initiatives ... then we as a smaller entity need to be } \\
\text { moving in that direction as well. (FHE3-II) }\end{array}$ & $\begin{array}{l}\text { Green League Table, } \\
\text { Peers, Competitions, } \\
\text { Position }\end{array}$ \\
\hline & $\begin{array}{l}\text { Student Satisfaction } \\
\text { [The aim to meet the increasing } \\
\text { expectations of students regarding } \\
\text { sustainability] }\end{array}$ & $\begin{array}{l}\text { - Quite often when we talk about sustainability, the opening statement from the members } \\
\text { [universities] is: oh no, the students will go mad if we do something like that; or students } \\
\text { are really big on this ... it's pleasing to hear that because there is an acute awareness of } \\
\text { who the customer is and the power that they ultimately have. (PC1) } \\
\text { - The student body are much more aware these days and they want to know that we are } \\
\text { doing our work in the right way in terms of environmental impact. (FHE4-I1) } \\
\text {-When we were studying in the university a long time ago we were not engaged in the } \\
\text { supply chain as the students are nowadays. They come with their own sustainability } \\
\text { wishes. (FHE5-II) }\end{array}$ & $\begin{array}{l}\text { Students, Customers, } \\
\text { Engaged, Awareness }\end{array}$ \\
\hline & Reduced Control & -The challenge is probably because you don't have direct day to day control. (FHE4-II) & Control, Gap \\
\hline
\end{tabular}




\begin{tabular}{|c|c|c|c|}
\hline \multirow{3}{*}{$\begin{array}{l}\text { Challenges of } \\
\text { Implementation of SP } \\
\text { (Outsourcing } \\
\text { Implementation Mode) } \\
\text { [The main challenges } \\
\text { that face outsourcing } \\
\text { universities when } \\
\text { implementing } \\
\text { sustainability } \\
\text { initiatives and } \\
\text { practices] }\end{array}$} & $\begin{array}{l}\text { [The universities have less control } \\
\text { over both: contractors' procurement } \\
\text { activities; and the sustainability } \\
\text { practices of their actual food and } \\
\text { catering suppliers] }\end{array}$ & $\begin{array}{l}\text {-I think one is that we just don't have enough control over things that are going on ... } \\
\text { you have to trust what they gonna do and what they say they gonna do .. but that is not } \\
\text { always the case. (FHE5-I2) } \\
\text {-Control is the main challenge ... I think it would be difficult for us to try to directly } \\
\text { manage to that level, that's why I was so keen that they get Food for Life and then I can } \\
\text { say ok if you do that then I know you are doing all those things in the criteria that are } \\
\text { included in Food for Life. (FHE5-II) }\end{array}$ & \\
\hline & $\begin{array}{l}\text { Contractors' Financial Interests } \\
\text { [The contractors prioritise their } \\
\text { company financial performance and } \\
\text { interests over the universities' } \\
\text { sustainability interests when there is } \\
\text { a conflict between these two } \\
\text { objectives] }\end{array}$ & $\begin{array}{l}\text {-For example, I recently met with the catering team from University X. They do } \\
\text { everything in-house and I got obsessed by how passionate they were about what they } \\
\text { were doing and especially the sustainable food dreams and the things that they have } \\
\text { already implemented. So you could feel that passion and see it in what they are doing, } \\
\text { but that is lacking here. With all the catering companies that I have worked with, at the } \\
\text { end of the day they look after their own pocket and their own company and all of that. } \\
\text { Although they do try to work with you, but because they actually don't work for the } \\
\text { University, I think that makes a big difference in how things are done and how people } \\
\text { work. (FHE5-I2) } \\
\text {-We often hear them say "well that's gonna cost more money for us to do that and if that } \\
\text { is the case then we have to undertake a review of whether there are alternative ways of } \\
\text { doing things that mitigate any additional cost" ... But I would say that more or less the } \\
\text { caterer will be happy as long as the university is happy to compensate the bill of any cost } \\
\text { increases of say for example changing to organic suppliers. (FHE4-I2) }\end{array}$ & Cost \\
\hline & $\begin{array}{l}\text { Reduced Flexibility } \\
\text { [The contractors are less flexible in } \\
\text { responding to changes in the } \\
\text { universities' sustainability } \\
\text { requirements over time] }\end{array}$ & $\begin{array}{l}\text {-Sometimes they [contractors] are not as flexible as they could be. If we directly } \\
\text { employed the staff we could tell them exactly what we want from them to do, but they are } \\
\text { not employed by us.... (FHE4-I2) } \\
\text {-I think what's difficult [in convincing the contractor] is when I can't come up with the } \\
\text { benefits to them well enough ... so it is like playing politics really, influencing people } \\
\text { and making them see the benefits of things. (FHE5-I2) }\end{array}$ & $\begin{array}{l}\text { (Meanings around } \\
\text { Flexibility) }\end{array}$ \\
\hline \multirow{2}{*}{$\begin{array}{l}\text { Facilitators of } \\
\text { Implementation of SP } \\
\text { (Outsourcing } \\
\text { Implementation Mode) } \\
\text { [The main facilitators } \\
\text { that help outsourcing } \\
\text { universities overcome } \\
\text { the challenges when } \\
\text { implementing }\end{array}$} & $\begin{array}{l}\text { Contractors' sustainability } \\
\text { competitive factors } \\
\text { [The market competition between } \\
\text { the contractors with regards to } \\
\text { sustainability offerings, as a means } \\
\text { to win tenders] }\end{array}$ & $\begin{array}{l}\text { - Some clients in universities, schools and colleges won't even think to do any business } \\
\text { with anybody unless they have the accreditations and they have the potential to do things } \\
\text { correctly ... yes now it has really high importance and I think the universities are coming } \\
\text { around to the idea that they need to do more as well. (Con2) } \\
\text { - Most of the decent sized firms when they are tendering they will be able to say we have } \\
\text { all of these certifications in place and they are measured and monitored on them. } \\
\text { (FHE5-II) }\end{array}$ & $\begin{array}{l}\text { Accreditation, } \\
\text { Certificates, Reputation }\end{array}$ \\
\hline & Collaborative relationship & $\begin{array}{l}\text {-So you have to build a good relationship that manages that control because you are } \\
\text { handing it to somebody else and you have to be able to trust what they do and what they } \\
\text { want to do. (FHE4-I1) }\end{array}$ & $\begin{array}{l}\text { Relationship, Trust, } \\
\text { Meetings, Work Together }\end{array}$ \\
\hline
\end{tabular}




\begin{tabular}{|c|c|c|c|}
\hline \multirow[t]{2}{*}{$\begin{array}{l}\text { sustainability } \\
\text { initiatives and } \\
\text { practices ] }\end{array}$} & $\begin{array}{l}\text { [Developing a good working } \\
\text { relationship with contractors } \\
\text { operations managers and chefs as a } \\
\text { means to increase control and } \\
\text { reduce the risks related to the } \\
\text { contractors' sustainability } \\
\text { performance] }\end{array}$ & $\begin{array}{l}\text {-We work together towards the university policy and that's great because we are new } \\
\text { here in the university so we get information about what the policy is, what they would } \\
\text { like to get and how we can help and support in that. (Con2) } \\
\text {-But we are working together, basically me saying the thing that I want them to do and } \\
\text { them saying ok, and on the things that they are not very agreeable with, I have to be very } \\
\text { diplomatic and find new ways to argue my case, it's tough. (FHE5-I2) }\end{array}$ & \\
\hline & $\begin{array}{l}\text { Sustainable contract management } \\
\text { [Having contracts that effectively } \\
\text { specify contractor requirements } \\
\text { with regards to sustainability } \\
\text { practices] }\end{array}$ & $\begin{array}{l}\text {-I found out that unless you actually specify exactly what you want them to do, you don't } \\
\text { have a leg to stand on because you have not said what you want them to achieve. (FHE5- } \\
\text { I2) } \\
\text {-There are penalties in the contract as well which would require the contract caterer to } \\
\text { pay us money if they don't hit certain targets... so there are various targets in the } \\
\text { contract that they need to meet, so if they didn't do that they have to pay us money. } \\
\text { (FHE4-I2) }\end{array}$ & $\begin{array}{l}\text { Contract, Tendering } \\
\text { Documents }\end{array}$ \\
\hline \multirow{2}{*}{$\begin{array}{l}\text { Supporting } \\
\text { Advantages for the } \\
\text { Sustainability-related } \\
\text { Strategic Objectives } \\
\text { (Outsourcing } \\
\text { Implementation Mode) } \\
\text { [The main advantages } \\
\text { that the universities } \\
\text { can gain from } \\
\text { outsourcing, that help } \\
\text { to achieve their } \\
\text { sustainability-related } \\
\text { strategic objectives] }\end{array}$} & $\begin{array}{l}\text { Professionalism } \\
\text { [Outsourcing to catering experts, } \\
\text { whose management staff have } \\
\text { greater sustainability-related } \\
\text { knowledge and experience] }\end{array}$ & $\begin{array}{l}\text {-You are also often going to large organisations that have a lot of specialism in } \\
\text { providing catering services ... so they have some people with a lot of experience and } \\
\text { they have good systems and practices. (FHE4-I2) } \\
\text {-I think we see that a catering company is much better at running catering than the } \\
\text { University would be. ... They are more experienced, they know their thing, they know } \\
\text { how to run catering and services. (FHE5-I2) } \\
\text { - Lastly what we found is that actually the client will choose us because of what we offer, } \\
\text { not only sustainability but the way that we buy our food and fresh food or our training } \\
\text { and innovation and everything. (Con1) }\end{array}$ & $\begin{array}{l}\text { Expert(ise), } \\
\text { Experience(d), Specialist }\end{array}$ \\
\hline & $\begin{array}{l}\text { Reduced costs } \\
\text { [Reducing SP implementation costs } \\
\text { through outsourcing to contractors } \\
\text { who carry those costs on behalf of } \\
\text { the universities] }\end{array}$ & $\begin{array}{l}\text {-so we get access to price arrangements that they have with food suppliers and also } \\
\text { access to the food expertise as well. With all contract arrangement there is a balance } \\
\text { between quality, cost and speed of reaction. (FHE5-I1) } \\
\text {-Also things like buying power is one of the advantages. The large catering companies } \\
\text { particularly when they operate in your locality they will have greater buying power upon } \\
\text { their suppliers. They would be able to dictate to the suppliers what they want, but for us } \\
\text { we are buying as a single institution and our choices will be much more limited and that } \\
\text { would probably give the suppliers the power rather than buyers. (FHE4-II) } \\
\text {-I think it is [cheaper] ... One of the interesting things is that when you outsource and } \\
\text { there is an invoice, they see a big fat invoice coming in. ... In in-house catering a lot of } \\
\text { the costs are hidden, they get absorbed in the [general] administration cost. For } \\
\text { example, there is a cost for the person who does the invoices or the payroll and this cost } \\
\text { is absorbed in the rest of the other [non- sustainable procurement] costs, you can't see it. } \\
\text { (Con1) }\end{array}$ & $\begin{array}{l}\text { Buying Power, Cheaper, } \\
\text { Cost }\end{array}$ \\
\hline
\end{tabular}




\begin{tabular}{|c|c|c|c|}
\hline & $\begin{array}{l}\text { Spreading risks } \\
\text { [Spreading SP implementation risks } \\
\text { through outsourcing to contractors } \\
\text { who carry those risks on behalf of } \\
\text { the universities] }\end{array}$ & $\begin{array}{l}\text {--If they [contractor] perform badly and didn't make any profit the whole loss will come } \\
\text { into their account because we are guaranteed a minimum amount of profit [e.g., Meat } \\
\text { Free Monday]. So the incentive for them is to run a good outlet which makes that } \\
\text { minimum level of profit. (FHE4-II) } \\
\text {-I think also it is a risky business. There's a lot that goes on behind providing food for } \\
\text { students and hospitality events (in terms of food safety and quality) and we are a } \\
\text { professional company. (Con2) }\end{array}$ & Risk, Lose/Loss \\
\hline \multirow{2}{*}{$\begin{array}{l}\text { Challenges of } \\
\text { Implementation } \\
\text { of SP (In-House } \\
\text { Implementation Mode) } \\
\text { [The main challenges } \\
\text { that face in-house } \\
\text { universities when } \\
\text { implementing } \\
\text { sustainability } \\
\text { initiatives and } \\
\text { practices] }\end{array}$} & $\begin{array}{l}\text { Increased costs } \\
\text { [Increased costs that the universities } \\
\text { carry to implement SP initiatives } \\
\text { and practices in-house] }\end{array}$ & $\begin{array}{l}\text {-From a departmental level, we obviously have to get as many sustainable things as we } \\
\text { can within the budget. (FHE1-I2) } \\
\text {-Cost is considered one of the main challenges because everything in the budget is very } \\
\text { tight, this is something that we can afford, but generally I have to offset it somewhere } \\
\text { else, or try and find a way that makes it work cheaper, it was like the initial costs with } \\
\text { supplier X [one of local organic vegetables suppliers]. (FHE2-I2) } \\
\text {--Challenges for sustainability are resources- financial and staff resources, .... we have } \\
\text { challenges on budgets. (FHE3-II) }\end{array}$ & $\begin{array}{l}\text { Cost, Budget, Price, } \\
\text { Afford(able/ability), } \\
\text { Finance(ial) }\end{array}$ \\
\hline & $\begin{array}{l}\text { Increased risks } \\
\text { [Increased risks that the universities } \\
\text { carry to implement SP initiatives } \\
\text { and practices in-house] }\end{array}$ & $\begin{array}{l}\text {-The other challenge is actually to get it to market, so to find a way to get it delivered, so } \\
\text { for instance for our organic milk, our fruit and veg supplier picks it up from the farmer } \\
\text { [the milk producer] he then delivers it on his behalf, so he is not bringing the vehicle } \\
\text { onto the campus, our fruit and veg man is coming to the campus anyway and delivers it } \\
\text { [i.e the fruit and veg supplier also deliver the organic milk on behalf of the farmer who } \\
\text { produces it] Before we got the fruit and veg supplier to deliver it, we did find difficulties } \\
\text { in delivering the organic milk to the campus. (FHE2-I1) } \\
\text {-It is, because change with chefs is not always a good thing, we're constantly reminded } \\
\text { that we didn't have this problem when we used, you know, Mr. Smith who was down by } \\
\text { the docks! (FHE3-I1) } \\
\text {-Catering has always been one of those areas where if you look at Christmas time and } \\
\text { the amount of free bottles and free this and free that that fly around from companies to } \\
\text { chefs... [creating a] risk element of people being accused of improper activity (PC2) }\end{array}$ & $\begin{array}{l}\text { (Meanings around } \\
\text { different types of risk } \\
\text { (financially and } \\
\text { operationally)) }\end{array}$ \\
\hline $\begin{array}{l}\text { Facilitators of } \\
\text { Implementation of SP } \\
\text { (In-House } \\
\text { Implementation Mode) } \\
\text { [The main facilitators } \\
\text { that help in-house } \\
\text { universities overcome } \\
\text { the challenges }\end{array}$ & $\begin{array}{l}\text { Increased Control } \\
\text { [The universities have more control } \\
\text { over internal buyers and chefs } \\
\text { which reduces the resistance } \\
\text { towards implementing } \\
\text { sustainability practices that have } \\
\text { been specified by the procurement } \\
\text { management team] }\end{array}$ & $\begin{array}{l}\text {-They have to buy in, you are always gonna get the pockets where they say we are not } \\
\text { doing this or not doing that, and I think that's where I have to be pig headed and go in } \\
\text { and say I'm not listening, we are doing it. But generally I try to work with them and say } \\
\text { "let's do this guys" and tell them the reason why so I try to sell it to them, but you always } \\
\text { get somebody that says "I am not doing that because we never did it before or whatever } \\
\text { the reason" and that's where I have to go "no we are doing it". (FHE2-I2) } \\
\text {-The procurement function in The University is currently being centralised under The } \\
\text { Procurement Department, which has a very good team that works in harmony. So, till }\end{array}$ & Buy in, Centralised \\
\hline
\end{tabular}




\begin{tabular}{|c|c|c|c|}
\hline \multirow{3}{*}{$\begin{array}{l}\text { associated with } \\
\text { implementing } \\
\text { sustainability } \\
\text { initiatives and } \\
\text { practices] }\end{array}$} & & $\begin{array}{l}\text { this moment, there is no resistance from team members towards this new food and } \\
\text { catering procurement initiatives. (FHE1-I4) }\end{array}$ & \\
\hline & $\begin{array}{l}\text { Sustainability passion } \\
\text { [The in-house catering team } \\
\text { generally is more passionate about } \\
\text { sustainability than the contractors } \\
\text { catering team] }\end{array}$ & $\begin{array}{l}\text {-Our team members ... have been instrumental in the work we have done with our milk } \\
\text { supplier in terms of being able to source local produce that also meets the requirements } \\
\text { of the compassionate well farming standard. So we have recently got the Good ECO } \\
\text { Award and Good Dairy Award ... we don't set out at the start of the year to say we going } \\
\text { to get this award because we do things fundamentally for the right reasons as opposed to } \\
\text { necessarily chasing an award. ... It is fundamentally about doing the right thing. } \\
\text { (FHE3-II) } \\
\text {-I am not that sort of person that goes and says ok fine its money or cost, I would rather } \\
\text { keep the quality and know that they [suppliers] are sustaining their business for next year } \\
\text { so it works both ways, I am not out to just screw somebody down on price until it } \\
\text { cripples them, I can't see the point in that, and we wouldn't do that, ethically it's not } \\
\text { right (FHE2-II) } \\
\text { - It is [sustainability] something that I've always been keen on personally. (FHE1-I2) }\end{array}$ & $\begin{array}{l}\text { People, Passion, Team, } \\
\text { Keen }\end{array}$ \\
\hline & $\begin{array}{l}\text { Purchasing consortiums' assistance } \\
\text { [The important role that catering } \\
\text { purchasing consortiums play in } \\
\text { helping the in-house universities to } \\
\text { implement sustainability initiatives, } \\
\text { both from the professional side } \\
\text { (e,g., procurement training, } \\
\text { conferences, competitions, } \\
\text { consultations and sharing best } \\
\text { practices) or by helping with the } \\
\text { procurement processes (e.g., } \\
\text { conducting tenders, checking } \\
\text { suppliers and facilitating best } \\
\text { prices)] }\end{array}$ & $\begin{array}{l}\text {-Using the purchasing consortium is a great help, because it's for them to ensure that } \\
\text { our suppliers are delivering in the best way possible, whether that's in the type of } \\
\text { vehicles that they use or the food that they are supplying, so knowing that our } \\
\text { purchasing consortium know what the university caterer is looking for is sustainability, } \\
\text { that helps. The purchasing consortium have also engaged with MSC (Marine } \\
\text { Stewardship Council) to allow us to get the accreditation much more easily and as a } \\
\text { whole university sector rather than just individual universities. The purchasing } \\
\text { consortium got involved with the Sustainable Restaurant Association and created an } \\
\text { audit plan specifically for universities, so they are always there to help. (FHE2-I1) } \\
\text {-We actually try to show cases of sustainable purchasing practices, and then what we } \\
\text { actually can do is to provide greater transparency within the contract that we have for } \\
\text { the sustainable initiatives and products, but it would be member led. (PC1) } \\
\text {-The other thing that is alarming in that is there are many cases over the years of } \\
\text { fraudulent activities. Catering has always been one of those areas where if you look at } \\
\text { Christmas time and the amount of free bottles and free this and free that that fly around } \\
\text { from companies to chefs. ... by making people use the framework you take away that risk } \\
\text { element of people being accused of improper activity and that is why we are going that } \\
\text { route. (PC2) }\end{array}$ & $\begin{array}{l}\text { Purchasing Consortium, } \\
\text { Suppliers Framework, } \\
\text { Help, Assistance, } \\
\text { Sharing, Development }\end{array}$ \\
\hline $\begin{array}{l}\text { Supporting } \\
\text { Advantages for the } \\
\text { Sustainability-related } \\
\text { Strategic Objectives }\end{array}$ & $\begin{array}{l}\text { Developing in-house expertise } \\
\text { [The procurement team is } \\
\text { continuously learning how to }\end{array}$ & $\begin{array}{l}\text {-I think it is the understanding in terms of how the environment's developing and } \\
\text { growing. As staff skills develop, they start to be able to influence suppliers and supply } \\
\text { chains in terms of elements of sustainability whereas potentially we haven't had that } \\
\text { opportunity historically to influence that. (FHE3-II) }\end{array}$ & $\begin{array}{l}\text { Staff./Employees/Team } \\
\text { Members, Skills, } \\
\text { Develop, Support }\end{array}$ \\
\hline
\end{tabular}




\begin{tabular}{|c|c|c|c|}
\hline \multirow{2}{*}{$\begin{array}{l}\text { (In-House } \\
\text { Implementation Mode) } \\
\text { [The main advantages } \\
\text { that the universities } \\
\text { can gain from using an } \\
\text { in-house } \\
\text { implementation mode, } \\
\text { that help to achieve } \\
\text { their sustainability- } \\
\text { related strategic } \\
\text { objectives] }\end{array}$} & $\begin{array}{l}\text { incorporate sustainability into their } \\
\text { practices which helps the university } \\
\text { to create a unique sustainable } \\
\text { service and differentiates it from } \\
\text { other universities] }\end{array}$ & $\begin{array}{l}\text {-5 years ago when I joined the university, this [sustainability] wasn't on the consortia } \\
\text { agenda. It is a domino effect and it seems to be a sort of ideal way to pursue } \\
\text { professionalism and we find we need to consider it more certainly. (FHE1-I1) } \\
\text {-Our team members are very happily involved in the purchasing for catering services } \\
\text { and have been instrumental in the work we have done with our milk supplier in terms of } \\
\text { being able to source local produce that also meets the requirements of the } \\
\text { compassionate well farming standard so we have recently got the Good ECO Award and } \\
\text { Good Dairy Award. (FHE3-I1) }\end{array}$ & \\
\hline & $\begin{array}{l}\text { Ongoing flexibility } \\
\text { [The internal buyers and chefs are } \\
\text { more flexible in coping with the } \\
\text { changes in the universities' } \\
\text { sustainability requirements over } \\
\text { time] }\end{array}$ & $\begin{array}{l}\text {-We are just about to move to fully compostable packaging from September and there is } \\
\text { a cost to the business and I have to offset that to somewhere else which I have done with } \\
\text { our food waste and things like that. So I am allowed to go and do that, and put that on } \\
\text { the table, so for example I will say that it will cost } £ 25,000 \text { this year extra, but I can } \\
\text { offset it by doing } x, y \text { and } z \text { with our food waste which will bring our costs down that } \\
\text { way, so I am allowed to go and do that. (FHE2-I2) } \\
\text {-Within reason, we haven't to stick to purchasing consortium suppliers, but we can go } \\
\text { outside if we need to buy local for example ... We've never really been pushed where } \\
\text { they [management] say you've got to just do it on price. (FHE1-I2) }\end{array}$ & $\begin{array}{l}\text { (Meanings around } \\
\text { Flexibility) }\end{array}$ \\
\hline
\end{tabular}

